\title{
14. MINERALOGY AND INORGANIC GEOCHEMISTRY OF SEDIMENTS FROM THE MOUTH OF THE GULF OF CALIFORNIA ${ }^{1}$
}

\author{
Victor B. Kurnosov, Far-East Geological Institute, USSR Academy of Sciences, Vladivostok, USSR \\ Ivar O. Murdmaa, Vera Kazakova, and Alla Shevchenko, P. P. Shirshov Institute of Oceanology, \\ USSR Academy of Sciences, Moscow, USSR \\ and \\ Vladlena Mikhina, Polytechnical Institute, Moscow, USSR
}

\section{INTRODUCTION}

During Leg 65,15 holes were drilled at four sites located on young crust in the mouth of the Gulf of California. Quaternary to upper Pliocene hemipelagic sediments above and interlayered within the young basaltic basement were cored. The influence of hot lava, high temperature gradients, and hydrothermal activity on the mineralogy and geochemistry of the terrigenous sediments near contacts with basalts might therefore be expected.

The purpose of the present study was to determine the mineralogy and inorganic geochemistry of these sediments and to analyze the nature and extent of low temperature alteration. To this end we studied the mineralogy and inorganic geochemistry of 75 sediment samples, including those immediately overlying uppermost basalts and those from layers alternating with basalts within the basement. We separated three size fractions$<2 \mu \mathrm{m}$ (clay), $2-20 \mu \mathrm{m}$ (intermediate), and $>20 \mu \mathrm{m}$ (coarse) - and applied the following mineralogical determinations: $x$-ray diffraction (XRD), infrared spectroscopy, transmission and scanning electron microscopy, and optical microscopy (for coarse fractions, using thin sections and smear slides). We calculated the percentages of clay minerals using Biscaye's (1964) method, and used routine wet chemical analyses to determine bulk composition and quantitative spectral analyses for trace elements.

\section{SITE 482}

Site 482 was located $12 \mathrm{~km}$ east of the East Pacific Rise and $15 \mathrm{~km}$ south of the Tamayo Fracture Zone. The age of the basement is about $0.5 \mathrm{~m}$.y. The thickness of upper Quaternary sediments above the basalt is 140 meters; these are olive gray hemipelagic clay or silty clay, with admixtures of nannofossils, foraminifers, radiolarians, and diatoms. Sedimentation rates vary from 343 to $548 \mathrm{~m} / \mathrm{m}$.y. The temperature at the sediment/basalt contact was $90^{\circ} \mathrm{C}$ in Hole $482 \mathrm{C}$, and the geothermal gradient calculated for the site equaled $67^{\circ}$ per 100 meters. Notwithstanding the high temperature, the basalts are no more altered than most of the oceanic tholeiites.

\footnotetext{
${ }^{1}$ Lewis, B. T. R., Robinson, P., et al., Init, Repts, DSDP, 65: Washington (U.S. Govt. Printing Office).
}

We studied sediments from five of the holes drilled at Site 482: Holes A, B, C, D, and F. Three samples are from sediments interlayered within basalts: Hole 482B$19-1,31-33 \mathrm{~cm}$ and $47-49 \mathrm{~cm}$, and Hole 482D-9-1, 3-7 $\mathrm{cm}$. Several samples were taken from sediments immediately overlying basement. Sample 482B-10-7, 4-6 cm represents a contact with basalt, Sample 482B-10-6, 139$141 \mathrm{~cm}$ was taken $15 \mathrm{~cm}$ above the contact. Sample $482 \mathrm{~F}-$ 4-3, 100-102 cm is from the sediment/basalt contact. Sample $482 \mathrm{C}-9-1,12-14 \mathrm{~cm}$ is from $40 \mathrm{~cm}$ above the contact. The lowermost sediment sample from Hole 482D (Core 7, Section 3, 145-147 cm) was recovered less than 4.5 meters above the first basalt sampled.

\section{Mineralogy}

It is clear from smear-slide and thin section analysis that the sediments at Site 482 are of terrigenous origin with an admixture of more or less abundant biogenic calcite (foraminifers, nannofossils, and unidentified fragments), minor biogenic opal (radiolarian and diatom fragments plus rare spicules), and organic matter (plant debris, sapropels), with variable amounts of the following authigenic minerals: pyrite, glauconite, carbonates of the dolomite-ankerite-siderite group, barite, and zeolite (clinoptilolite).

The terrigenous matter is composed of clay minerals and clastic grains of quartz, feldspar, (mainly plagioclase), mica, and heavy minerals such as epidote, zircon, amphiboles, and apatite. The clastic minerals are concentrated in the silt and fine sand fractions, where quartz and feldspars predominate. The relative abundance of clastic minerals therefore varies with the average grain size.

Pyrite occurs throughout the sediment section and commonly predominates over the other authigenic minerals. As indicated visually in smear slides, it amounts up to 1 to $3 \%$ total sediment composition, but tends to increase with depth. The common forms are microspherules, 2 to $20 \mu \mathrm{m}$ in diameter or less, which occur separately in the clay matrix or concentrated on organic matter fragments, foraminifer tests, etc. Along with spherules we observed irregular aggregates of pyrite and pyrite pseudomorphs after plant debris. Cubic crystals are rare.

The authigenic carbonates seem to vary widely in composition, as indicated by differences in color and re- 
fractive index. Yellowish or reddish brown grains with high refractive indices are likely those of ferroan dolomite (ankerite) or siderite, whereas light yellow or colorless crystals probably represent dolomite. The carbonates are unevenly distributed in the section. The first rare ankerite(?) crystals were noted in the uppermost sample, Sample 482A-1-1, 130-133 cm (1.3 m sub-bottom). Downward in different holes, mineral abundance varies from zero or traces to 1 to $2 \%$ of total sediment composition.

Sample $482 \mathrm{C}-8-1,106-108 \mathrm{~cm}$ (131 m sub-bottom) is composed almost totally of fine-grained, rhombohedral ankerite(?) crystals, 5-7 $\mu \mathrm{m}$ in diameter, with both refractive indices of all grains in thin section higher than that of Canadian balsam (1.54). The x-ray diffraction pattern of the $2-20 \mu \mathrm{m}$ fraction showed almost pure dolomite, but the high refractive index indicates that it is ferroan. The sample also contains subordinant amounts of spheroidal pyrite, elongated organic particles (plant debris?), and an admixture (1-2\%) of clastic quartz and clay minerals.

Relatively abundant authigenic carbonates (of about $3 \%$ ) were observed in a smear slide of Sample 482C-9-1, $12-14 \mathrm{~cm}$ (132.12 m sub-bottom, $40 \mathrm{~cm}$ above the basalt), where rhombohedral crystals and microdruses as large as $30 \mu \mathrm{m}$ occur. The carbonates are also common in samples higher above the basement: Sample 482C-76, 25-27 cm (128 m sub-bottom), Sample 482D-1-1, $120-123 \mathrm{~cm}$ (77 m sub-bottom), Sample 482D-4-2, 135$137 \mathrm{~cm}$ (103 m sub-bottom), and Sample 482D-5-2, 61$63 \mathrm{~cm}$ (111.6 m sub-bottom), and in a sample from sediments interbedded within basalts: Sample 482B-19-1, 47-49 cm (193.5 m sub-bottom).

Zeolite (clinoptilolite) crystals, commonly less than $20 \mu \mathrm{m}$ across, occur sporadically in the upper portion of the section and disappear below 100 to 125 meters subbottom, where the present temperature is higher than $60^{\circ} \mathrm{C}$. In our set of samples the zeolite is most abundant in sediments from Hole $482 \mathrm{~A}$, Cores 1 and 3 .

Barite was observed in several thin sections and in smear slides from the lower part of the sediment section, particularly in sediments immediately overlying basalt (Samples 482B-10-7, 4-6 cm and 482C-9-1, 12-14 cm) or intercalated within basalts (Sample 482B-19-1, 47-49 $\mathrm{cm})$, but also in Samples 482D-5-2, 60-63 cm and 482F$3-4,88-90 \mathrm{~cm})$ (111.6 $\mathrm{m}$ and $128 \mathrm{~m}$ sub-bottom). The mineral occurs as spherulitic aggregates, 0.3 to $1 \mathrm{~mm}$ in diameter, of platy colorless crystals, which show low birefringence, a refractive index higher than 1.54, and positive elongation. The crystals contain numerous inclusions of surrounding sediment particles and are obviously of authigenic origin.

$\mathrm{X}$-ray diffraction studies, in general, confirmed and refined the identifications made by smear-slide and thinsection analysis. In particular, these studies demonstrated the presence of smectites (17 $\AA$ minerals), mica, mixed-layer illite-montmorillonite (+mica), chlorite, kaolinite, mixed-layer chlorite-montmorillonite (swelling chlorite), quartz, feldspars, clinoptilolite, calcite, dolomite, an amorphous phase, and pyrite.
In the clay fraction $(<2 \mu \mathrm{m})$ (Table 1) smectite predominates throughout the section, showing rather irregular variations between 60 and 88 vol. $\%$. The greater values tend to occur in the lower parts of the sediment section-below 100 meters-in Holes 482B, D, and F; but in two samples in Hole $482 \mathrm{C}, 131$ to 132 meters subbottom, we detected low percentages of the mineral. Smectites are absent in the clay fraction immediately overlying basalts and interbedded within basalts in Hole 482D (samples from $133 \mathrm{~m}$ and $141.5 \mathrm{~m}$ sub-bottom).

The smectite $d$-spacing ranges from 12.2 to $12.6 \AA$ and increases to values of 16.8 to $17 \AA$ when the samples are treated with glycol. The ratio between the shoulder heights of the $17 \AA$ peak, which we propose to name coefficient $z$, and which characterizes the peak asymmetry, averages 0.6 . In the crystal structure of the smectite a minor number of mica layers may exist. The smectites display a dioctahedral structure. Treatment with $10 \% \mathrm{HCl}$ indicates that they comprise both aluminous and ferric montmorillonite (Table 2). Low $\mathrm{Fe}_{2} \mathrm{O}_{3}$ content in samples rich in smectite (Table 3 ) confirm the presence of $\mathrm{Al}$-montmorillonite. In the sediments just above basalts the Al-montmorillonite predominates over the ferric variety, but in layers intercalated with basalts the two varieties occur in almost equal quantities (Table 2).

Mica and chlorite (the latter detected with kaolinite) occur in minor amounts in the clay fraction. The mica has a dioctahedral structure and is rich in aluminum and ferric iron. Chlorite is trioctahedral with a stable defect structure and tends to be ferro-magnesian in composition. Kaolinite is clearly recognizable on the diffraction diagrams only after treatment with hot $10 \% \mathrm{HCl}$ (Table 2). The kaolinite was generally recognized both in unaltered sediments and in sediments which made contact with basalts or were intercalated within basalts. However, in Hole 482D near the sediment/basalt contact (Sample 482D-7-3, 146-147 cm) and in sediments intercalated within basalts (Sample 482D-9-1, 3-7 cm), kaolinite is absent and the clay fraction is composed of swelling chlorite (Table 1 ) and a mixed-layer illite-montmorillonite containing 20 to $30 \%$ mica. The latter mineral is characterized by a peak between 10.73 and 10.94 $\AA$ on the diffraction diagrams for dry samples. When the samples are treated with glycol, the peak shifts to 9.91-9.93 $\AA$ and an additional peak appears at 11-12 $\AA$. After heating at $550^{\circ} \mathrm{C}$ for one hour, the peak shifts to $10.0-10.4 \AA$. The mineral is insoluble in hot $10 \%$ $\mathrm{HCl}$ and its morphology is shown on Plate 1, Figure 3, and Plate 2, Figure 2.

The swelling chlorite contains minor amounts of montmorillonite in its structure. The diffraction diagrams for dry samples show peaks at $14.16 \AA, 7.09 \AA$, $4.70 \AA$, and $3.53 \AA$ (Sample 482D-7-3, 146-147 cm). After treatment with glycol, the basal reflection shifts to $14.25 \AA$. After heating, the entire series of peaks disappeared except for a single peak at $13.59 \AA$. The mineral is soluble in hot $10 \% \mathrm{HCl}$.

Clinoptilolite was found by X-ray diffraction only in the upper part of the sediment section cored at Site 482 . 
It disappears below 124 meters ( $14 \mathrm{~m}$ above basement) in Holes A and B and below 100 meters (33-38 m above basement) in Hole D.

Other minerals occur in the clay fraction, but usually only in trace amounts. In one sample, however (Sample 482C-8-1, 106-108 cm) we observed abundant dolomite (in thin section it resembles ankerite), and several samples from the lowermost portions of the section contain much quartz (Table 1). In Sample 482A-5-7, 23-26 cm we detected traces of actinolite.

Except for clinoptilolite and quartz the dominant minerals are almost equally distributed throughout the sediment section in Holes A, B, and F, including the sediments immediately overlying or inside the basement. Sediments from 129 to 132 meters sub-bottom in Hole C contain in the clay fraction less smectite (35-69\%) and more mica $(23-50 \%)$ than those from the same depth in other holes. The clay fraction of those sediments in contact with basalts and from layers intercalated within basalts in Hole D is composed of unusual clay mineralsswelling chlorite and mixed-layer illite-montmorillonite (+ mica) likely of hydrothermal origin. Smectites near the basalts in all holes display "authigenic" features on SEM photographs.

The intermediate and coarse fractions (2-20 $\mu \mathrm{m}$ and $>20 \mu \mathrm{m}$, respectively) are markedly enriched in quartz and feldspars in comparison with the clay fraction. In several samples the mica content is also enriched in the coarse fraction (Table 1), but commonly the compositions of the clay minerals in the two fractions are quite similar. The two lowermost samples from Hole 482D, taken just above and inside the basement, for example, contain in the fraction ranging from $2-20 \mu \mathrm{m}, 87$ and $90 \%$ mixed-layer illite-montmorillonite (+ mica) with 13 and $10 \%$ swelling chlorite, as does the clay fraction of the same samples. Interestingly, a coarse sample from just above the basement in Hole 482C (Core 8, Section 1, 106-108 cm) is almost wholly composed of dolomite (ankerite) with a minor admixture of clay minerals and quartz.

On the diffraction diagrams for dry, coarse fractions, peaks at $12.2-12.6 \AA$ and $13.8-14 \AA$ are easily recognizable. Treatments with glycol, with hot $10 \% \mathrm{HCl}$, and with heat (at $550^{\circ} \mathrm{C}$ ) indicate that the $13.8-14 \AA$ peak belongs partly to chlorite, but mainly to smectite. The latter is ferric montmorillonite, soluble in hot $10 \% \mathrm{HCl}$ (Table 2). Therefore, the coarse fractions contain a variety of Fe-montmorillonite with a peak at 13.8-14 $\AA$, which we have not observed in the clay fraction. The swelling chlorite in coarse fractions of the above-mentioned two samples from Hole 482D contains less smectite than the swelling chlorite in clay fractions.

We also studied the mineralogy of the coarse $(>20$ $\mu \mathrm{m})$ fraction in 10 samples of Site 482 sediments using the immersion method (Table 3 ). Heavy-mineral content in these samples ranges from traces to $2.2 \%$. It is composed of 59 to $100 \%$ authigenic pyrite. In six samples we found barite ( 0.4 to $34.3 \%$ of the heavy minerals) in platy crystals and angular fragments containing abundant inclusions of clay and pyrite, likely indicative of authigenic origin of the mineral. Barite is common only be- low 128 meters sub-bottom. Heavy minerals of terrigenous origin are represented by epidote and zircon with minor hornblende, clinopyroxene, apatite, rutile, anatase, corundum, chlorite, and sphene.

The light fraction consists largely of quartz and feldspar which are present in roughly equal amounts. Most of the feldspars show refraction indexes less than 1.54, and are thus sodium plagioclase (albite-oligoclase) and potassium feldspars. In three samples we found gypsum, and in the two uppermost samples, zeolite.

\section{Geochemistry}

We determined bulk composition both for bulk sediments and for two size fractions: clay and intermediate (Table 4). Ten samples were analyzed from Site 482 , but in only six of them was the amount sufficient to analyze both fractions. The set includes three samples from immediately overlying basement and one from sediments intercalated within basalts. Two samples from Hole 482D, Cores 7 and 9 (Table 4) contain hydrothermal(?) mixed-layer illite-montmorillonite (+ mica) and swelling chlorite; two samples from the same hole (Cores 1 and 5) represent sediments with authigenic carbonates.

The chemical composition of the sediments is uniform, close to that of common hemipelagic mud, almost irrespective of distance from basaltic basement. $\mathrm{SiO}_{2}$ content in bulk samples ranges from 53 to $58 \%$ (Table 4), as in common hemipelagic mud. The silica to alumina ratio $\left(\mathrm{SiO}_{2} / \mathrm{Al}_{2} \mathrm{O}_{3}\right)$ in most samples is close to that of average clay (3.5), or somewhat higher (up to 3.8), likely as a result of high terrigenous quartz content. In a sample taken just above basalt (Sample 482F-4-3, 100 $102 \mathrm{~cm}$ ) we detected the lowest value of the ratio (3.2). The sample contains less quartz than others, and the smectite content is high.

Silica is apparently concentrated in the intermediate fraction (60-65\% $\mathrm{SiO}_{2}$; ratio of $\mathrm{SiO}_{2}$ to $\left.\mathrm{Al}_{2} \mathrm{O}_{3}, 4.2-4.7\right)$, where $\mathrm{x}$-ray data show the highest quartz and feldspar content. The clay fraction is relatively low in $\mathrm{SiO}_{2}$ (51-55\%) and rich in $\mathrm{Al}_{2} \mathrm{O}_{3}$ (up to $20.3 \%$ near the sediment/basalt contact in Sample 482D-7-3, 145-147 cm), composed mainly of mixed layer illite-montmorillonite (+ mica), whereas in another sample just above basalt (Sample 482B-10-7, 4-6 cm) the clay fraction is relatively enriched in silica.

Titanium content is consistently low throughout, close to that in common hemipelagic clay. The clay fraction is slightly enriched in titanium as compared with the $2-20 \mu \mathrm{m}$ fraction. The aluminum to titanium ratio, which is sensitive to the presence of volcaniclastic material (Boström, 1976; Murdmaa et al., 1979, 1980) is similar for bulk samples and fractions, ranging from 19 to 24 , the values indicative of terrigenous clay and mud.

Iron content is low both in bulk samples and fractions (Table 3 ). We have not recognized any noticeable enrichment in iron near the sediment/basalt contact or in the sediments intercalated within basalt. The total iron and $\mathrm{Fe}_{2} \mathrm{O}_{3}$ are somewhat higher in the intermediate fraction and lower in the clay fraction, the state of oxidation showing an apparent decrease in the latter. In two samples of the clay fraction from Hole D, where 
Table 1. Mineralogy of sediment fractions, Site 482 (in percent).

\begin{tabular}{|c|c|c|c|c|c|c|c|c|c|c|c|c|c|c|c|}
\hline $\begin{array}{c}\text { Sample } \\
\text { (interval in } \mathrm{cm} \text { ) }\end{array}$ & $\begin{array}{l}\text { Sub-bottom } \\
\text { Depth } \\
\text { (m) }\end{array}$ & Lithology & Age & Smectite & Mica & $\begin{array}{c}\text { Mixed-layer } \\
\text { Illite-Montmorillonite } \\
\text { plus Mica }\end{array}$ & Chlorite & $\begin{array}{c}\text { Mixed-layer } \\
\text { Chlorite- } \\
\text { Montmorillonite }\end{array}$ & $\mathrm{Z}$ & Quartz & Clinoptilolite & $\begin{array}{l}\text { Amorphous } \\
\text { Phase }\end{array}$ & Calcite & Feldspar & Dolomite \\
\hline \multicolumn{16}{|c|}{ Clay $(<2 \mu \mathrm{m})$ sediment fraction } \\
\hline \multicolumn{16}{|l|}{ Hole 482A } \\
\hline $1-1,130-133$ & 1.3 & Unit I silty clay & Upper Quaternary & 70 & 20 & & 10 & $\operatorname{tr}$ & 0.5 & tr & $\mathrm{c}$ & $\mathrm{tr}$ & & tr & \\
\hline $3-1,103-106$ & 16.63 & & & 60 & 25 & & 15 & tr & 0.4 & tr & c & tr & & tr & \\
\hline $5-7,23-26$ & 43.73 & & & 70 & 20 & & 10 & & 0.5 & tr & $\mathrm{c}$ & tr & & tr & \\
\hline \multicolumn{16}{|l|}{ Hole 482B } \\
\hline $2-2,88-90$ & 55.88 & Unit 1 clay and & & 75 & 15 & & 10 & & 0.6 & $\mathrm{tr}$ & c & $\mathrm{tr}$ & & tr & \\
\hline $4-1,130-133$ & 73.80 & silty clay & & 65 & 25 & & 10 & & 0.4 & tr & c & tr & & tr & \\
\hline $7-2,94-96$ & 103.44 & & & 75 & 18 & & 7 & tr & 0.5 & tr & c & tr & & tr & \\
\hline $9-3,123-125$ & 124.23 & & & 80 & 17 & & 5 & & 0.6 & tr & c & tr & & tr & \\
\hline $9-6,118-120$ & 128.68 & & & 75 & 17 & & 8 & & 0.6 & tr & & tr & & tr & \\
\hline $10-4,42-44$ & 134.42 & & & 80 & 14 & & 6 & & 0.6 & tr & & tr & & tr & \\
\hline $10-4,102-104$ & 135.02 & & & 78 & 15 & & 7 & & 0.6 & tr & & tr & & tr & \\
\hline $10-5,102-104$ & 136.52 & & & 72 & 20 & & 8 & tr & 0.6 & c & & to & & tr & \\
\hline $10-6,139-141$ & 138.39 & & & 76 & 16 & & 8 & tr & 0.6 & c & & to & & tr & \\
\hline $10-7,4-6^{\mathrm{a}}$ & 138.54 & & & 75 & 14 & & 11 & & 0.6 & c & & tr & & tr & \\
\hline $19-1,31-33^{b}$ & 193.31 & Indurated silty clay & & 73 & 22 & & 5 & & 0.5 & tr & & tr & & tr & \\
\hline $19-1,47-49^{b}$ & 193.47 & and mudstone & & 73 & 18 & & 9 & & 0.5 & tr & & tr & & tr & \\
\hline \multicolumn{16}{|l|}{ Hole $482 \mathrm{C}$} \\
\hline $7-6,25-27$ & 128.25 & Unit I silty clay & Upper Quaternary & 69 & 23 & & 8 & & 0.5 & $\operatorname{tr}$ & & $\operatorname{tr}$ & & tr & \\
\hline $8-1,106-108$ & 131.06 & & & 50 & 35 & & 15 & & 0.4 & c & & tr & tr & tr & c \\
\hline $9-1,12-14^{\mathrm{a}}$ & 132.12 & & & 35 & 50 & & 15 & & 0.3 & c & & tr & & tr & \\
\hline \multicolumn{16}{|l|}{ Hole 482D } \\
\hline $1-4,120-123$ & 77.20 & Unit 1 silty clay & Upper Quaternary & 62 & 24 & & 14 & tr & 0.4 & tr & c & tr & & tr & \\
\hline $4-2,135-137$ & 102.85 & & & 88 & 9 & & 3 & & 0.6 & tr & & tr & & tr & \\
\hline $5-2,60-63$ & 111.60 & & & 85 & 9 & & 7 & & 0.6 & tr & & ts & & tr & \\
\hline $6-3,21-23$ & 122.21 & & & 70 & 20 & & 10 & & 0.3 & tr & & tr & & tr & \\
\hline $7-3,145-147^{\mathrm{a}}$ & 132.95 & & & & & 94 & 6 & & & tr & & tr & & tr & \\
\hline $9-1,3-7^{b}$ & 141.53 & $\begin{array}{l}\text { Nannofossil-bearing } \\
\text { silty clay }\end{array}$ & & & & 93 & 7 & & & tr & & tr & & tr & \\
\hline \multicolumn{16}{|l|}{ Hole $482 \mathrm{~F}$} \\
\hline $3-4,88-90$ & 128.38 & Unit I silty clay & Upper Quaternary & 80 & 13 & & 7 & & 0.6 & tr & tr & tr & & tr & \\
\hline $4-2,38-40$ & 133.88 & & & 82 & 14 & & 4 & & 0.5 & tr & & tr & & tr & \\
\hline $4-3,46-49$ & $\begin{array}{l}135.46 \\
\end{array}$ & & & 83 & 11 & & 6 & & 0.6 & tr & & tr & & $\begin{array}{l}\text { to } \\
\text { tr }\end{array}$ & \\
\hline $4-3,100-102^{a}$ & 136.00 & & & 81 & 13 & & 6 & & 0.6 & tr & & tr & & tr & \\
\hline \multicolumn{16}{|c|}{ Intermediate $(2-20 \mu \mathrm{m})$ sediment fraction } \\
\hline \multicolumn{16}{|l|}{ Hole $482 \mathrm{~A}$} \\
\hline $1-1,130-133$ & 1.3 & Unit I silty clay & Upper Quaternary & 48 & 43 & & 9 & tr & 0.7 & d & d & tr & & d & \\
\hline $3-1,103-106$ & 16.63 & & & 45 & 44 & & 11 & tr & 0.6 & d & d & tr & & d & \\
\hline $5-7,23-26$ & 43.73 & & & 65 & 28 & & 7 & tr & 0.6 & d & c & c & & & c \\
\hline \multicolumn{16}{|l|}{ Hole 482B } \\
\hline $2-2,88-90$ & 55.88 & Unit I clay and & & 81 & 14 & & 5 & tr & 0.7 & c & c & to & & tr & \\
\hline $4-1,130-133$ & 73.80 & silty clay & & 63 & 32 & & 5 & tr & 0.6 & d & c & tr & & c & \\
\hline $7-2,94-96$ & 103.44 & & & 70 & 22 & & 8 & tr & 0.5 & d & c & tr & & c & \\
\hline
\end{tabular}




\begin{tabular}{|c|c|c|c|c|c|c|c|c|c|c|c|c|c|c|c|}
\hline $9-3,123-125$ & 124.23 & & & 87 & 9 & & 4 & tr & 0.7 & c & c & $\operatorname{tr}$ & & c & \\
\hline $9-6,118-120$ & 128.68 & & & 69 & 25 & & 6 & tr & 0.6 & d & & tr & $\operatorname{tr}$ & c & \\
\hline $10-4,42-44$ & 134.42 & & & 50 & 37 & & 13 & tr & 0.7 & d & & tr & & d & \\
\hline $10-4,102-104$ & 135.02 & & & 79 & 14 & & 7 & $\operatorname{tr}$ & 0.6 & c & & tr & & c & \\
\hline $10-5,102-104$ & 136.52 & & & 74 & 16 & & 10 & tr & 0.6 & d. & & c & & d & \\
\hline $10-6,139-141$ & 138.39 & & & 70 & 20 & & 10 & tr & 0.6 & d & & tr & & c & \\
\hline $10-7,4-6^{\mathrm{a}}$ & 138.54 & & & 65 & 24 & & 11 & tr & 0.5 & d & & tr & & d & \\
\hline $19-1,31-33^{b}$ & 193.31 & Indurated silty clay & & 88 & 7 & & 5 & $\operatorname{tr}$ & 0.6 & d & & tr & & c & \\
\hline $19-1,47-49^{b}$ & 193.47 & and mudstone & & 77 & 15 & & 8 & $\operatorname{tr}$ & 0.6 & d & & tr & & c & \\
\hline \multicolumn{16}{|l|}{ Hole $482 \mathrm{C}$} \\
\hline $7-6,25-27$ & 128.25 & Unit I silty clay & Upper Quaternary & 64 & 29 & & 7 & $\operatorname{tr}$ & 0.5 & d & & c & & c & \\
\hline $8-1,106-108$ & 131.06 & & & tr & tr & & & & & c & & tr & & tr & d \\
\hline $9-1,12-14^{\mathrm{a}}$ & 132.12 & & & 52 & 40 & & 8 & $\operatorname{tr}$ & 0.3 & d & & tr & tr & & \\
\hline \multicolumn{16}{|l|}{ Hole $482 \mathrm{D}$} \\
\hline $1-4,120-123$ & 77.20 & Unit I silty clay & Upper Quaternary & 68 & 23 & & 9 & $\operatorname{tr}$ & 0.5 & c & c & tr & & c & \\
\hline $4-2,135-137$ & 102.85 & & & 79 & 14 & & 7 & tr & 0.6 & d & & tr & & c & \\
\hline $5-2,60-63$ & 111.60 & & & 71 & 22 & & 7 & tr & 0.5 & d & & tr & & c & \\
\hline $6-3,21-23$ & 122.21 & & & 65 & 27 & & 8 & & 0.3 & d & & $\mathrm{c}$ & & c & \\
\hline $7-3,145-147^{\mathrm{a}}$ & 132.95 & & & & & 87 & 13 & & & d & & tr & & c & \\
\hline $9-1,3-7^{b}$ & 141.53 & $\begin{array}{l}\text { Nannofossil-bearing } \\
\text { silty clay }\end{array}$ & & & & 90 & 10 & & & d & & tr & & c & \\
\hline \multicolumn{16}{|l|}{ Hole $482 \mathrm{~F}$} \\
\hline $3-4,88-90$ & 128.38 & Unit I silty clay & Upper Quaternary & 78 & 16 & & 6 & $\operatorname{tr}$ & 0.6 & d & $\mathrm{c}$ & tr & & d & \\
\hline $4-2,38-40$ & 133.88 & & & 63 & 28 & & 9 & & 0.5 & d & & tr & & c & \\
\hline $4-3,46-49$ & 135.46 & & & 74 & 20 & & 6 & tr & 0.5 & c & & tr & & c & \\
\hline $4-3,100-102^{\mathrm{a}}$ & 136.00 & & & 72 & 18 & & 10 & tr & 0.6 & c & & tr & & c & \\
\hline \multicolumn{16}{|c|}{ Coarse $(>20 \mu \mathrm{m})$ sediment fraction } \\
\hline \multicolumn{16}{|l|}{ Hole $482 \mathrm{~A}$} \\
\hline $3-1,103-106$ & 16.63 & Unit I silty clay & Upper Quaternary & 71 & 23 & & 6 & tr & 0.7 & d & c & c & & d & \\
\hline \multicolumn{16}{|l|}{ Hole 482B } \\
\hline $9-6,118-120$ & 128.68 & Unit I clay and & & 75 & 20 & & 5 & tr & 0.6 & c & & $\mathrm{tr}$ & $\operatorname{tr}$ & $\mathrm{c}$ & \\
\hline $10-4,102-104$ & 135.02 & silty clay & & 70 & 22 & & 8 & tr & 0.5 & d & & tr & & $\mathrm{c}$ & \\
\hline $10-7,4-6$ & 138.54 & & & 75 & 15 & & 10 & tr & 0.7 & $\mathrm{~d}$ & & & & & \\
\hline \multicolumn{16}{|l|}{ Hole $482 \mathrm{C}$} \\
\hline $9-1,12-14$ & 132.12 & Unit I silty clay & & 54 & 35 & & 11 & tr & 0.3 & d & & $\mathrm{tr}$ & & c & \\
\hline \multicolumn{16}{|l|}{ Hole 482D } \\
\hline $5-2,60-69$ & 111.60 & Unit 1 silty clay & & 81 & 12 & & 7 & tr & 0.4 & c & & c & & c & \\
\hline $9-1,3-7^{a}$ & 114.53 & & & & & 9: & 5 & & & d & & $\mathrm{tr}$ & & $\mathbf{c}$ & \\
\hline \multicolumn{16}{|l|}{ Hole $482 \mathrm{~F}$} \\
\hline $3-4,88-90$ & 128.38 & Unit I silty clay & & 61 & 29 & & 10 & tr & 0.6 & d & c & d & & d & \\
\hline $4-3,100-102^{\mathrm{a}}$ & 136.00 & & & 76 & 15 & & 9 & tr & 0.6 & d & & c & & c & \\
\hline
\end{tabular}

a Sediments immediately overlying basement.

Sediments intercalated within basalts.

d Moderate.

Abundant.
$\mathrm{Tr}=$ trace. 
Table 2. Results of acid dissolution tests on sediments from Sites 482, 483, 484, and 485 .

\begin{tabular}{|c|c|c|c|}
\hline \multirow{2}{*}{$\begin{array}{c}\text { Sample } \\
\text { (interval in } \mathrm{cm} \text { ) }\end{array}$} & \multirow{2}{*}{$\begin{array}{l}\text { Sub-bottom } \\
\text { Depth } \\
(\mathrm{m})\end{array}$} & \multicolumn{2}{|c|}{ Sediments Tested ${ }^{\mathrm{a}}$} \\
\hline & & Clay Fraction $(<2 \mu \mathrm{m})$ & 2-20 $\mu \mathrm{m}$ Fraction \\
\hline \multicolumn{4}{|l|}{ Hole $482 \mathrm{~A}$} \\
\hline $5-7,23-26$ & 43.73 & Montmorillonite $<$ Fe-montmorillonite & Montmorillonite $<\mathrm{Fe}$-montmorillonite, kaolinite \\
\hline \multicolumn{4}{|l|}{ Hole 482B } \\
\hline $\begin{array}{l}10-7,4-6^{\mathrm{b}} \\
19-1,31-33^{\mathrm{c}} \\
19-1,37-49^{\mathrm{c}}\end{array}$ & $\begin{array}{l}138.54 \\
193.31 \\
193.47\end{array}$ & $\begin{array}{l}\text { Montmorillonite }>\mathrm{Fe} \text {-montmorillonite, kaolinite } \\
\text { Montmorillonite } \approx \mathrm{Fe} \text {-montmorillonite, kaolinite } \\
\text { Montmorillonite } \approx \mathrm{Fe} \text {-montmorillonite, kaolinite }\end{array}$ & \\
\hline \multicolumn{4}{|l|}{ Hole $482 \mathrm{C}$} \\
\hline $9-1,12-14^{b}$ & 132.12 & Montmorillonite $>$ Fe-montmorillonite, kaolinite & \\
\hline \multicolumn{4}{|l|}{ Hole 482D } \\
\hline $\begin{array}{l}5-2,60-63 \\
9-1,3-7^{c}\end{array}$ & $\begin{array}{l}111.60 \\
141.53\end{array}$ & $\begin{array}{l}\text { Montmorillonite }>\text { Fe-montmorillonite, kaolinite } \\
\text { Mixed-layer mineral insoluble, chlorite } \\
\text { dissolved, kaolinite absent }\end{array}$ & \\
\hline \multicolumn{4}{|l|}{ Hole $482 \mathrm{~F}$} \\
\hline $4-3,100-102^{b}$ & 136.00 & Montmorillonite $>\mathrm{Fe}$-montmorillonite, kaolinite & \\
\hline \multicolumn{4}{|l|}{ Hole 483} \\
\hline $\begin{array}{l}7-5,90-92 \\
13-3,50-52^{\mathrm{b}} \\
18-2,55-57^{\mathrm{c}} \\
18-4,63-65^{\mathrm{c}}\end{array}$ & $\begin{array}{r}55.40 \\
109.00 \\
153.05 \\
156.13\end{array}$ & $\begin{array}{l}\text { Montmorillonite }>\mathrm{Fe} \text {-montmorillonite, kaolinite } \\
\text { Montmorillonite }>\mathrm{Fe} \text {-montmorillonite, kaolinite } \\
\text { Montmorillonite } \leq \mathrm{Fe} \text {-montmorillonite, kaolinite } \\
\text { Montmorillonite } \leq \mathrm{Fe} \text {-montmorillonite, kaolinite }\end{array}$ & $\begin{array}{l}\text { Montmorillonite } \approx \mathrm{Fe} \text {-montmorillonite, kaolinite } \\
\text { Montmorillonite \& Fe-montmorillonite, kaolinite } \\
\text { Montmorillonite \& Fe-montmorillonite }\end{array}$ \\
\hline \multicolumn{4}{|l|}{ Hole $484 \mathrm{~A}$} \\
\hline $6-5,23-25^{b}$ & & Montmorillonite $\leq \mathrm{Fe}$-montmorillonite, kaolinite & \\
\hline \multicolumn{4}{|l|}{ Hole 485} \\
\hline $1-2,90-94$ & 2.40 & Montmorillonite $=\mathrm{Fe}$-montmorillonite, kaolinite & \\
\hline \multicolumn{4}{|l|}{ Hole 485A } \\
\hline $\begin{array}{l}1-5,120-124 \\
5-3,111-115 \\
11-2,107-111 \\
11-3,35-37^{b} \\
20, C C^{c} \\
26-1,48-50^{c} \\
28-1,148-150^{c} \\
38-1,98-100^{c}\end{array}$ & $\begin{array}{r}52.10 \\
92.61 \\
148.07 \\
158.35 \\
197.02 \\
226.48 \\
236.48 \\
313.98\end{array}$ & $\begin{array}{l}\text { Montmorillonite }>\mathrm{Fe} \text {-montmorillonite, kaolinite } \\
\text { Montmorillonite }=\mathrm{Fe} \text {-montmorillonite, kaolinite } \\
\text { Montmorillonite }>\mathrm{Fe} \text {-montmorillonite, kaolinite } \\
\text { Montmorillonite }<\mathrm{Fe} \text {-montmorillonite, kaolinite } \\
\text { Montmorillonite }<\mathrm{Fe} \text {-montmorillonite } \\
\text { Mixed-layer mineral insoluble } \\
\text { Mixed-layer mineral dissolved }\end{array}$ & $\begin{array}{l}\text { Montmorillonite \& Fe-montmorillonite, kaolinite } \\
\text { Montmorillonite } \leq \mathrm{Fe} \text {-montmorillonite, kaolinite }\end{array}$ \\
\hline
\end{tabular}

we detected hỷdrothermal(?) authigenic clay minerals (mixed-layer illite-montmorillonite (+ mica) and swelling chlorite), $\mathrm{FeO}$ even predominates over $\mathrm{Fe}_{2} \mathrm{O}_{3}$, whereas in other samples the latter is 1.5 to 2.3 times higher than $\mathrm{FeO}$. In the $2-20 \mu$ m fraction, the $\mathrm{Fe}_{2} \mathrm{O}_{3}$ to $\mathrm{FeO}$ ratio increases up to 6.2 , likely as a result of higher $\mathrm{Fe}$ montmorillonite content.

Manganese commonly shows low values throughout the set of samples analyzed, without any increasing trend toward basalts. We did not notice any evidence of exhalative or hydrothermal Mn precipitation.

Magnesium content does not show any significant variation. It is higher in the clay fraction as a result of concentration in clay minerals, but does not increase in the sediments with mixed-layer illite-montmorillonite (+ mica) and swelling chlorite. Variations in calcium content are likely caused by biogenic calcite.

Sodium and potassium content depend on their association with clay minerals and feldspars, so their distribution is rather irregular. However, we can observe a trend toward increasing $\mathrm{K}_{2} \mathrm{O}$ content downhole as well as in the $\mathrm{K}_{2} \mathrm{O}$ to $\mathrm{Na}_{2} \mathrm{O}$ ratio in the clay fraction. The greatest values of the ratio (3.6-4.4) occur below 110 meters in the clay fraction of samples from the sedi- ment/basalt contact and from a layer inside basement. Total alkalinity, expressed as $\mathrm{K}_{2} \mathrm{O}+\mathrm{Na}_{2} \mathrm{O} / \mathrm{Al}_{2} \mathrm{O}_{3}$ ranges from 0.16 to 0.46 without any distinct relation to distance from basalts. It is lower in the clay fraction as a result of higher aluminum content.

Phosphorus content is evenly low throughout the section.

Trace elements in all holes studied at Site 482 show similar distribution patterns (Table 5). In bulk samples the trace elements are rather evenly distributed irrespective of their proximity to basalts, except for boron, which decreases markedly near the sediment/basalt contact and in sediments intercalated within basalts. The latter samples show relatively low Mo and $\mathrm{Ni}$ contents as well. Concentrations of all trace elements studied in bulk samples are similar to those in common hemipelagic sediments, for example to those drilled during Legs 56 and 57 in the Japan trench (Murdmaa et al., 1980), although $\mathrm{Co}$ and $\mathrm{Cu}$ contents are lower and $\mathrm{Ni}$ and $\mathrm{Zn}$ contents somewhat higher in the sediments from the mouth of the Gulf of California.

In the clay fraction, distribution of most of the trace elements is also rather uniform, no apparent changes occurring either near the sediment/basalt contact or in 
Table 3. Mineralogy of the coarse ( $>20 \mu \mathrm{m}$ ) sediment fraction as determined by the immersion method, Sites $482,483,484$, and 485 .

\begin{tabular}{|c|c|c|c|c|c|c|c|c|c|c|c|c|c|c|c|c|c|c|c|c|c|c|c|c|}
\hline \multirow[b]{2}{*}{$\begin{array}{c}\text { Sample } \\
\text { (interval in cm) }\end{array}$} & \multicolumn{16}{|c|}{$\begin{array}{l}\text { Heavy Minerals } \\
\text { (percent of total) }\end{array}$} & \multicolumn{8}{|c|}{$\begin{array}{l}\text { Light Minerals a } \\
\text { (percent of total) }\end{array}$} \\
\hline & $\begin{array}{l}\text { Black } \\
\text { opaques }\end{array}$ & $\begin{array}{c}\text { Fe- } \\
\text { oxides }\end{array}$ & Pyrite & Garnet & $\begin{array}{l}\text { Horn- } \\
\text { blende }\end{array}$ & $\begin{array}{c}\text { Clino- } \\
\text { pyroxene }\end{array}$ & Epidote & Zircon & Apatite & Rutile & Anatase & Corundum & Sphene & Biotite & Barite & Carbonates & Quartz & Feldspar & Mica & $\begin{array}{c}\text { Opal } \\
\text { (biogenic) }\end{array}$ & $\begin{array}{l}\begin{array}{l}\text { Carbonate } \\
\text { (biogenic) }\end{array} \\
\text { (bog }\end{array}$ & Zeolite & Gypsum & Opal(? $)^{\text {b }}$ \\
\hline $482 \mathrm{~B}-2-2,88-90$ & 1 & - & 80 & - & 1 & - & 10 & 6 & 1 & + & + & - & - & - & 1 & - & 17 & 24 & - & - & - & 2 & 2 & 7 \\
\hline $482 \mathrm{~B}-10-4,42-44$ & $i$ & - & 78 & - & - & - & 5 & i & $i$ & - & - & - & - & - & 14 & - & 28 & 20 & + & + & $=$ & $i$ & - & 9 \\
\hline $482 C-7-6,25-27$ & - & - & 79 & - & - & - & i & + & - & - & - & - & - & - & 19 & - & 3 & 4 & - & - & I & - & - & - \\
\hline $482 \mathrm{C}-8-1,106-108$ & - & 2 & 95 & - & - & + & + & + & - & - & + & + & - & - & + & - & 2 & - & - & - & - & - & 1 & - \\
\hline $482 \mathrm{D}-1-4,120-123$ & 1 & 2 & 76 & - & 2 & - & 14 & 3 & 2 & - & - & - & + & - & - & - & 16 & 23 & - & 2 & - & - & - & 10 \\
\hline $482 \mathrm{D}-4-2,135-137$ & - & 2 & 93 & - & - & + & - & 3 & + & - & - & 1 & - & - & - & - & 20 & 16 & - & - & 2 & - & 6 & 6 \\
\hline $482 \mathrm{D}-6-3,21-23$ & - & - & 100 & - & - & - & - & $\overline{2}$ & - & - & - & - & - & - & - & - & 15 & 16 & + & - & - & - & - & 4 \\
\hline $\begin{array}{l}482 \mathrm{D}-7 \cdot 3,145-147^{\mathrm{C}} \\
482 \mathrm{~F}-\mathrm{2} \cdot 38-40\end{array}$ & $\bar{z}+x+x+1$ & 1 & $\begin{array}{l}96 \\
84\end{array}$ & $\bar{z}+x+2+$ & \pm & $\bar{z}+$ & $\overline{1}$ & ${ }_{2}^{2}$ & $\begin{array}{c}1 \\
+ \\
\end{array}$ & \pm & $\bar{z}+1+3$ & $\bar{z}+x+2+$ & $\bar{z}+x+2$ & $\bar{z}+2+1$ & $\overline{12}$ & \pm & 26 & $\begin{array}{l}5 \\
35\end{array}$ & $\overline{-}$ & - & $\bar{z}+$ & $=$ & - & -3 \\
\hline $\begin{array}{l}482 \mathrm{~F}-4-2,38-40 \\
482 \mathrm{~F}-3,3,46-49 \mathrm{C}\end{array}$ & 2 & $\overline{1}$ & $\begin{array}{l}84 \\
59\end{array}$ & $\bar{z}$ & $\mp$ & $\overline{-}$ & - & $\begin{array}{l}2 \\
1\end{array}$ & ${ }_{2}^{+}$ & $\overline{-}$ & $\overline{-}$ & $\overline{7}$ & $\overline{-}$ & $\overline{-}$ & $\begin{array}{l}122 \\
34\end{array}$ & $\overline{-}$ & $\begin{array}{r}23 \\
4\end{array}$ & $\begin{aligned} 35 \\
6\end{aligned}$ & $\bar{z}$ & $\bar{z}$ & $\bar{z}$ & $\bar{z}$ & $\bar{z}+1+3$ & 3 \\
\hline $483-9-2,60-62$ & - & - & 90 & - & 3 & + & 5 & i & 1 & - & - & - & + & - & ${ }^{34}$ & $\mp$ & 27 & 22 & $\overline{3}$ & $\overline{2}$ & $\bar{z}+x+x+$ & $\overline{-}$ & $\bar{z}+$ & $\overline{-}$ \\
\hline $483 \cdot-12-3,88-90$ & - & - & 95 & - & 3 & - & - & - & - & - & - & - & - & 2 & - & - & - & - & - & - & - & - & - & - \\
\hline $483-13-1,120-122$ & 4 & - & 61 & + & 2 & - & 17 & 3 & 3 & - & - & - & + & - & - & - & 26 & 40 & 1 & - & - & - & - & 6 \\
\hline $483 \mathrm{~B}-2-6,693-97$ & 1 & $\bar{z}+$ & $\begin{array}{l}72 \\
93\end{array}$ & $\bar{z}+x+x+$ & 2 & $\bar{z}+$ & 19 & 3 & 2 & $\bar{z}+x+2 \cdot$ & $\bar{z}+x+3+$ & $\bar{z}+$ & $=$ & $\bar{z}+$ & + & - & 30 & 39 & 2 & - & - & - & - & 3 \\
\hline $\begin{array}{l}484 \mathrm{~A}-6-5,23-25^{\mathrm{C}} \\
485-3-5,9-9\end{array}$ & $\overline{8}$ & $\overline{+}$ & $\begin{array}{l}93 \\
60\end{array}$ & I & ${ }_{3}^{3}$ & $\bar{z}+x+1+x$ & $20^{3}$ & $\frac{1}{5}$ & $t_{2}^{+}$ & $\overline{+}$ & $\bar{z}$ r r r & $\bar{z}$ & $\bar{z}+x+2 \cdot$ & - & $\bar{z}$ & $\bar{z}+x+2 \cdot$ & 14 & 13 & 2 & 9 & 1 & - & - & 2 \\
\hline $\begin{array}{l}485 A-3-2,5-9 \\
485-4-1,63-66\end{array}$ & 4 & + & $\begin{array}{l}60 \\
58\end{array}$ & $\begin{array}{l}+ \\
+\end{array}$ & 3 & $\overline{-}$ & $\begin{array}{l}20 \\
28\end{array}$ & 3 & $\frac{2}{4}$ & \pm & $=$ & $\overline{-}$ & $=$ & 1 & $=$ & $\bar{z}+$ & ${ }^{21}$ & $\begin{array}{r}27 \\
9\end{array}$ & 1 & $\bar{z}$ & $\overline{-}$ & 1 & $\overline{-}$ & -3 \\
\hline $485 \mathrm{~A}-5-3,111-115$ & 9 & - & 48 & 2 & - & 3 & 28 & 6 & 3 & - & - & - & - & - & - & - & 22 & 19 & - & $\overline{2}$ & - & - & 3 & 3 \\
\hline $485 \mathrm{~A}-6-4,110-114$ & 9 & - & 70 & - & 1 & - & 14 & 5 & - & - & - & - & - & - & - & - & 31 & 45 & 1 & 7 & - & - & - & 8 \\
\hline 485A-9-1, $128-132$ & 16 & 3 & 52 & + & i & 2 & 19 & 5 & 1 & + & + & - & - & - & + & - & 10 & 10 & $i$ & - & - & - & 2 & - \\
\hline $485 \mathrm{~A}-10-2,104-107$ & s & - & 71 & - & 1 & + & 20 & 6 & 2 & - & - & - & - & - & - & - & 16 & 14 & - & - & - & - & - & 10 \\
\hline $485 \mathrm{~A}-19-2,40-42^{\mathrm{d}}$ & 5 & - & 63 & z & 6 & $\overline{-}$ & 18 & 6 & 1 & 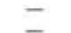 & $\bar{z}$ & - & + & $\bar{z}+x \cdot+x-1$ & - & $\bar{z}+$ & 20 & 11 & - & - & 2 & - & - & 4 \\
\hline $\begin{array}{l}20, C^{4} \mathrm{~A}-22-2,24-26^{\mathrm{d}} \\
{ }^{2}\end{array}$ & $\overline{4}_{4}$ & $z$ & $\begin{array}{r}100 \\
53\end{array}$ & $\beth$ & $\overline{2}$ & $\bar{z}+x+x-1$ & $\overline{23}$ & $\overline{3}$ & $\overline{2}$ & $\bar{z}+x+x$ & $\bar{z}+x+x+$ & $\bar{z}+x+x$ & $\overline{-}$ & $\bar{z}+x+a+1$ & $\overline{13}$ & $\overline{-}$ & $\begin{array}{l}20 \\
18\end{array}$ & $\begin{array}{l}12 \\
12\end{array}$ & $=$ & $\overline{-}$ & 2 & $\bar{z}$ & 1 & ${ }^{3}$ \\
\hline $485 \mathrm{~A}-22-4,33-3$ & 10 & - & 44 & + & $=$ & - & 33 & 6 & 2 & - & - & - & - & 1 & 4 & - & 26 & 29 & - & - & 2 & - & - & 7 \\
\hline $485 \mathrm{~A}-27-1,46-48^{\mathrm{d}}$ & 3 & - & 56 & - & 4 & - & 24 & 3 & 2 & - & - & - & - & - & 8 & - & - & - & - & - & - & - & - & - \\
\hline $485 \mathrm{~A}-34-1,33-35^{\mathrm{d}}$ & 5 & 1 & 69 & - & + & - & 16 & 3 & 2 & - & - & - & - & - & 4 & - & 20 & 26 & - & - & - & - & - & 4 \\
\hline $485 \mathrm{~A}-36-1,61-65^{\mathrm{a}}$ & - & - & 93 & - & - & - & 6 & 1 & + & - & - & - & - & - & - & - & 9 & 16 & - & - & - & - & - & 2 \\
\hline
\end{tabular}

The remainder of the light fraction is composed of clay pellets, rock fragments, and altered minerals.

"Opal?" is an unidentified isotropic colorless mineral with a low refraction index, of authigenic appearance.

d Sediments immediately overlying basement. 
Table 4. Chemical composition of sediments, Site 482 .

\begin{tabular}{|c|c|c|c|c|c|c|c|c|c|c|c|c|c|c|}
\hline \multirow[b]{3}{*}{ Component } & \multicolumn{14}{|c|}{$\begin{array}{c}\text { Sample } \\
\text { (interval in } \mathrm{cm} \text { ) }\end{array}$} \\
\hline & \multicolumn{2}{|c|}{$482 \mathrm{~A}-3-1,103-106$} & \multicolumn{3}{|c|}{$482 \mathrm{~B}-9-3,123-125$} & \multirow{2}{*}{$\frac{482 \mathrm{~B}-10-7,4-6^{\mathrm{a}}}{<2 \mu \mathrm{m}}$} & \multicolumn{3}{|c|}{$482 \mathrm{D}-1-4,120-123$} & \multicolumn{2}{|c|}{$482 \mathrm{D}-5-2,60-63$} & \multicolumn{3}{|c|}{$482 \mathrm{D}-7-3,145-147^{\mathrm{a}}$} \\
\hline & Bulk & $<2 \mu \mathrm{m}$ & Bulk & $2-20 \mu \mathrm{m}$ & $<2 \mu \mathrm{m}$ & & Bulk & $2-20 \mu \mathrm{m}$ & $<2 \mu \mathrm{m}$ & Bulk & $<2 \mu \mathrm{m}$ & Bulk & $2-20 \mu \mathrm{m}$ & $<2 \mu \mathrm{m}$ \\
\hline $\mathrm{SiO}_{2}$ & 53.96 & 51.40 & 55.12 & 59.80 & 54.92 & 59.78 & 52.66 & 61.60 & 53.60 & 57.02 & 54.74 & 57.80 & 65.31 & 52.86 \\
\hline $\mathrm{TiO}_{2}$ & 0.58 & 0.79 & 0.58 & 0.60 & 0.64 & 0.64 & 0.62 & 0.62 & 0.77 & 0.62 & 0.73 & 0.66 & 0.56 & 0.85 \\
\hline $\mathrm{Al}_{2} \mathrm{O}_{3}$ & 14.35 & 17.70 & 14.88 & 13.98 & 13.46 & 15.48 & 15.39 & 13.66 & 16.67 & 15.56 & 18.09 & 17.18 & 13.85 & 20.28 \\
\hline $\mathrm{Fe}_{2} \mathrm{O}_{3}$ & 2.96 & 3.53 & 2.93 & 3.51 & 2.38 & 3.39 & 3.04 & 4.19 & 3.38 & 2.41 & 2.78 & 2.89 & 3.60 & 2.18 \\
\hline $\mathrm{FeO}$ & 1.29 & 1.46 & 1.29 & 1.09 & 1.60 & 1.26 & 1.77 & 0.67 & 1.47 & 1.43 & 1.36 & 2.04 & 1.07 & 2.48 \\
\hline $\mathrm{MnO}$ & 0.06 & 0.07 & 0.12 & 0.12 & 0.16 & 0.08 & 0.05 & 0.07 & 0.05 & 0.08 & 0.06 & 0.05 & 0.04 & 0.03 \\
\hline $\mathrm{MgO}$ & 2.92 & 3.06 & 2.90 & 2.49 & 4.18 & 2.74 & 2.09 & 1.61 & 2.66 & 2.90 & 2.98 & 2.34 & 2.01 & 3.71 \\
\hline $\mathrm{CaO}$ & 3.35 & 0.78 & 2.58 & 1.57 & 1.34 & 0.67 & 3.69 & 1.45 & 0.67 & 3.58 & 1.01 & 2.57 & 0.67 & 0.11 \\
\hline $\mathrm{Na}_{2} \mathrm{O}$ & 2.84 & 0.87 & 2.36 & 1.67 & 0.87 & 1.50 & 2.83 & 3.17 & 0.82 & 2.60 & 0.62 & 2.08 & 2.09 & 0.90 \\
\hline $\mathrm{K}_{2} \mathrm{O}$ & 2.50 & 2.02 & 2.50 & 2.75 & 1.85 & 3.56 & 3.01 & 3.05 & 2.31 & 2.50 & 2.25 & 3.11 & 3.35 & 3.65 \\
\hline $\mathrm{P}_{2} \mathrm{O}_{5}$ & 0.26 & 0.18 & 0.26 & 0.20 & 0.22 & 0.18 & 0.14 & 0.31 & 0.19 & 0.24 & 0.15 & 0.18 & 0.22 & 0.14 \\
\hline LÖI & 14.6 & 18.1 & 13.9 & 11.7 & 17.8 & 10.5 & 14.30 & 9.10 & 16.8 & 10.7 & 14.9 & 8.90 & 6.70 & 12.40 \\
\hline Total & 99.67 & 99.96 & 99.42 & 99,48 & 99.42 & 99.78 & 99.59 & 99.80 & 99.39 & 99.64 & 99.67 & 99.80 & 99.47 & 99.59 \\
\hline $\mathrm{K}_{2} \mathrm{O} / \mathrm{Na}_{2} \mathrm{O}$ & 0.88 & 2.32 & 1.06 & 1.64 & 2.13 & 2.37 & 1.06 & 0.96 & 2.82 & 0.96 & 3.63 & 1.50 & 1.60 & 4.06 \\
\hline $\mathrm{K}_{2} \mathrm{O}+\mathrm{Na}_{2} \mathrm{O} / \mathrm{Al}_{2} \mathrm{O}_{3}$ & 0.37 & 0.16 & 0.33 & 0.32 & 0.20 & 0.33 & 0.38 & 0.46 & 0.19 & 0.33 & 0.16 & 0.30 & 0.39 & 0.22 \\
\hline $\mathrm{Fe}_{2} \mathrm{O}_{3}+\mathrm{FeO}+\mathrm{MgO} / \mathrm{Al}_{2} \mathrm{O}_{3}$ & 0.50 & 0.45 & 0.48 & 0.51 & 0.61 & 0.48 & 0.45 & 0.47 & 0.45 & 0.43 & 0.39 & 0.42 & 0.48 & 0.41 \\
\hline $\mathrm{SiO}_{2} / \mathrm{Al}_{2} \mathrm{O}_{3}$ & 3.76 & 2.90 & 3.70 & 4.28 & 4.08 & 3.86 & 3.42 & 4.51 & 3.21 & 3.66 & 3.02 & 3.36 & 4.71 & 2.61 \\
\hline $\mathrm{Fe}$ & 3.08 & 3.61 & 3.06 & 3.31 & 2.91 & 3.35 & 3.51 & 3.45 & 3.51 & 2.80 & 3.01 & 3.61 & 3.35 & 3.46 \\
\hline $\mathrm{Al} / \mathrm{Ti}$ & 21.71 & 19.96 & 22.54 & 20.58 & 18.76 & 21.58 & 22.02 & 19.57 & 19.19 & 22.30 & 21.79 & 23.33 & 21.59 & 21.08 \\
\hline
\end{tabular}

Note: Values shown in weight percent.

a Sediments immediately overlying basement.

b Sediments intercalated within basalts.

sediments within basalts. $\mathrm{Cu}, \mathrm{Cr}$, and $\mathrm{V}$ are somewhat concentrated in the clay fraction as compared with bulk samples but $\mathrm{Ni}$ and $\mathrm{Pb}$ are lower in the clay fraction.

Most of the trace elements, except for $\mathrm{Cr}$ and $\mathrm{V}$, are relatively enriched in the intermediate fraction (Table 5), and the composition of this fraction is quite variable, depending clearly on the location of samples in the sediment section relative to basalts. A sharp increase in $\mathrm{Cu}$, $\mathrm{Zn}$, and $\mathrm{Ag}$ concentrations in the fraction coincides with the presence of authigenic pyrite, so we assume that most of the trace elements are associated with this mineral. An alternative or additional association may exist between the trace elements and $\mathrm{Fe}$-montmorillonite, relatively more abundant in the intermediate fraction.

There is a rather irregular though apparent downhole increase in $\mathrm{Cu}, \mathrm{Ni}, \mathrm{V}, \mathrm{Pb}, \mathrm{Zn}$, and $\mathrm{Ag}$ content and a less obvious increase in Co and Sn content; there is no increase in $\mathrm{B}, \mathrm{Cr}$, and Mo. Except for Mo, the highest concentrations of the trace elements were detected in the 2-20 $\mu \mathrm{m}$ fraction of Sample 482B-10-5, 102-104, about 2 meters above the basement, where $\mathrm{Cu}$ content is as high as $850 \mathrm{ppm}$; Ni, $900 \mathrm{ppm}$; $\mathrm{Ag}, 6.0 \mathrm{ppm}$; Sn, 63 $\mathrm{ppm}$; and $\mathrm{Pb}, 129 \mathrm{ppm}$. In smear slide, this sample is observed to be a common silty clay, which contains about $2 \%$ pyrite. The clay fraction from sediment/basalt contacts and layers intercalated within basalts are less enriched in the trace elements, although average trace element values for these sediments (Table 5) are higher, than those for the upper portion of the section. Hydrothermal redistribution may explain the enrichment in trace elements of lower parts of the section along with reducing conditions, resulting in pyrite precipitation.

\section{SITE 483}

Site 483 is located $52 \mathrm{~km}$ west of the crest of the East Pacific Rise and about $25 \mathrm{~km}$ east of Baja California continental slope. Thickness of sediments above basaltic basement is 110 meters. These are Quaternary, hemipelagic silty clays, lithologically similar to those at Site 482. The layers intercalated within basalts are of late Pliocene age. In Hole $483 \mathrm{C}$ temperature measured at the base of the sediments was $30^{\circ} \mathrm{C}$.

We studied sediment samples from Holes 483 and 483B. Two of these are from layers intercalated within basalt (Samples 483-18-2, 55-57 cm and 483-19-4, 63-65 $\mathrm{cm})$; another two were taken from just above the basement (Samples 483-13-3, 50-52 cm, 1 meter above the contact and 483B-2-6, 93-97 cm, $0.5 \mathrm{~m}$ above the contact with uppermost basalts).

\section{Mineralogy}

The mineralogy of the Site 483 sediments, as determined in smear slides and thin sections is similar to that at Site 482 . The sediments are composed mainly of terrigenous clay minerals, quartz, feldspars, and mica flakes with minor admixtures of biogenic calcite and opal in the upper part of the section, and minor organic matter fragments and authigenic pyrite throughout.

Pyrite occurs throughout the sediment section, but in our samples from Unit I we found less than $1 \%$ by volume of the mineral (according to visual estimation in smear slides), whereas in Unit III below 70 meters subbottom it is much more abundant (up to $4-6 \%$ ). In some samples the pyrite aggregates display the shape of barite crystals. These may be either skeletal crystals of barite or pyrite pseudomorphs after barite.

Barite was found in thin sections and smear slides of samples taken just above basement (Samples 483-12-3, $88-90 \mathrm{~cm}, 483-13-3,50-52 \mathrm{~cm}$, and 483B-2-6, 93-97 cm) and from sediments intercalated within basalt (Sample $483-18-2,55-57 \mathrm{~cm}$ ). In thin section the mineral occurs as radial spherulitic aggregates, 0.3 to $0.7 \mathrm{~mm}$ in diameter. The platy crystals of barite contain numerous clay particles and pyrite. In a smear slide (Sample 483-12-3, $88-90 \mathrm{~cm}$ ), we observed a euhedral barite crystal, 0.05 
Table 4. (Continued).

\begin{tabular}{|c|c|c|c|c|c|c|c|c|c|c|c|}
\hline & & & \multirow{2}{*}{\multicolumn{3}{|c|}{$\begin{array}{c}\text { Sample } \\
\text { (interval in cm) } \\
482 \mathrm{~F}-3-4,88-90\end{array}$}} & \multirow{3}{*}{$\frac{482 \mathrm{~F}-4-3,46-49}{<2 \mu \mathrm{m}}$} & & & \multicolumn{3}{|c|}{$\begin{array}{l}\text { Sediments Overlying } \\
\text { Basement Av. Comp. }\end{array}$} \\
\hline \multicolumn{3}{|c|}{ 482D-9-1, 3-7b } & & & & & \multicolumn{2}{|c|}{$482 \mathrm{~F}-4-3,100-102^{\mathrm{a}}$} & Bulk & $2-20 \mu \mathrm{m}$ & $<2 \mu \mathrm{m}$ \\
\hline Bulk & $2-20 \mu \mathrm{m}$ & $<2 \mu \mathrm{m}$ & Bulk & $2-20 \mu \mathrm{m}$ & $<2 \mu \mathrm{m}$ & & Bulk & $2-20 \mu \mathrm{m}$ & $(n=5)$ & $(n=3)$ & $(n=6)$ \\
\hline 56.18 & 65.10 & 54.55 & 53.34 & 62.90 & 54.25 & 53.87 & 54.28 & 62.31 & 54.42 & 61.43 & 53.80 \\
\hline 0.64 & 0.56 & 0.81 & 0.64 & 0.58 & 0.68 & 0.73 & 0.60 & 0.60 & 0.61 & 0.60 & 0.72 \\
\hline 16.43 & 14.28 & 19.99 & 14.95 & 15.42 & 18.89 & 18.13 & 16.46 & 14.88 & 15.03 & 14.35 & 17.16 \\
\hline 3.06 & 3.66 & 1.89 & 3.90 & 4.05 & 3.02 & 2.88 & 3.46 & 4.32 & 3.05 & 3.92 & 3.00 \\
\hline 1.87 & 1.47 & 2.68 & 1.43 & 0.87 & 1.47 & 1.27 & 1.33 & 0.94 & 1.44 & 0.88 & 1.44 \\
\hline 0.07 & 0.05 & 0.04 & 0.06 & 0.04 & 0.03 & 0.04 & 0.06 & 0.04 & 0.07 & 0.08 & 0.07 \\
\hline 2.01 & 1.85 & 3.06 & 2.28 & 1.29 & 2.50 & 2.42 & 2.21 & 1.85 & 2.62 & 1.80 & 2.97 \\
\hline 4.37 & 0.56 & 0.45 & 3.92 & 0.89 & 0.45 & 1.23 & 3.69 & 0.34 & 3.42 & 1.30 & 0.91 \\
\hline 2.25 & 2.09 & 0.98 & 2.27 & 2.25 & 0.86 & 0.78 & 2.27 & 1.92 & 2.58 & 2.36 & 0.80 \\
\hline 3.02 & 3.35 & 3.55 & 3.32 & 3.55 & 3.05 & 3.45 & 3.22 & 4.25 & 2.77 & 3.12 & 2.49 \\
\hline 0.12 & 0.15 & 0.18 & 0.19 & 0.24 & 0.27 & 0.15 & 0.18 & 0.27 & 0.22 & 0.25 & 0.39 \\
\hline 9.50 & 6.70 & 11.40 & 13.20 & 7.50 & 13.90 & 14.50 & 11.9 & 7.9 & 13.34 & 9.43 & 16.00 \\
\hline 99.52 & 99.82 & 99.58 & 99.50 & 99.58 & 99.32 & 99.45 & 99.66 & 99.62 & & & \\
\hline 1.34 & 1.60 & 3.62 & 1.46 & 1.58 & 3.55 & 4.42 & 1.42 & 2.21 & 1.08 & 1.39 & 3.14 \\
\hline 0.32 & 0.38 & 0.23 & 0.37 & 0.38 & 0.21 & 0.23 & 0.33 & 0.41 & 0.36 & 0.39 & 0.15 \\
\hline 0.42 & 0.49 & 0.38 & 0.51 & 0.40 & 0.37 & 0.36 & 0.42 & 0.48 & 0.47 & 0.46 & 0.44 \\
\hline 3.42 & 4.56 & 2.73 & 3.56 & 4.08 & 2.87 & 2.97 & 3.29 & 4.18 & & & \\
\hline 3.60 & 4.01 & 3.41 & 3.84 & 3.51 & 3.26 & 3.01 & 3.46 & 3.75 & & & \\
\hline 22.92 & 22.94 & 22.06 & 20.84 & 23.34 & 24.41 & 21.84 & 24.22 & 21.88 & & & \\
\hline
\end{tabular}

mm long, with a large pyrite spherule included. Carbonate crystals seem to replace barite in some cases.

Zeolite (clinoptilolite) occurs as small crystals and irregular grains in most smear slides, but its frequency is variable, and it disappears in the Pliocene sediments intercalated within the basement.

Carbonates of the dolomite-ankerite(?) group occur below 34 meters sub-bottom as very small rhombic crystals. Their frequency increases below 70 meters subbottom, but we have not found any samples with high concentrations of the minerals.

$\mathrm{X}$-ray diffraction data for the clay and intermediate fractions show that clay mineral assemblage is similar to that of Site 482 , but smectite content is lower and mica content is higher in the clay fraction and particularly in the intermediate fraction (Table 6). In a sample of nearsurface sediments ( $4 \mathrm{~m}$ sub-bottom), mica even predominates over smectite. The sediments near basement and those intercalated within basalts show a slight increase in smectite in the clay fraction.

Clinoptilolite occurs in both fractions down to sediment/basement contact, but was not detected by x-ray diffraction in sediments intercalated within basalt. In several samples below 90 meters sub-bottom it is abundant.

Four samples of the coarse $(>20 \mu \mathrm{m})$ fraction, from an interval 70 to 109 meters sub-bottom, were analyzed by the immersion method (Table 3 ) and found to contain 1.7 to $6.5 \%$ heavy minerals, somewhat more than we estimated at Site 482 . Pyrite predominates in the heavy fraction (61-95\%) in all samples. Other authigenic heavy minerals are virtually absent: we found only a single grain of barite. Terrigenous minerals are represented by the epidote group (which predominates), plus hornblende, zircon, and apatite with rare garnet, clinopyroxene, rutile, and sphene. The assemblage is similar to that at Site 482 , but the hornblende content is somewhat higher.
The light fraction consists almost entirely of quartz and feldspars, the latter commonly predominating. Zeolite and gypsum were not found.

\section{Geochemistry}

In bulk samples, concentrations of the trace elements studied (Table 7) are similar (Cr, Mo, Sn) or higher (B, $\mathrm{Co}, \mathrm{Cu}, \mathrm{Ni}, \mathrm{V}, \mathrm{Pb}, \mathrm{Zn}, \mathrm{Ag}$ ) than those at Site 482. Such elements as $\mathrm{B}, \mathrm{Cu}, \mathrm{Mo}, \mathrm{Ni}$, and $\mathrm{Zn}$ are more concentrated in the upper portion of the section, whereas sediments immediately overlying basement and within the basalt show lower concentrations. Other elements are either evenly distributed throughout the set of samples or show irregular variations irrespective of distance from basalts. The general order of relative abundance of elements at Site 483 is the same as at Site 482 .

The intermediate fraction $(2-20 \mu \mathrm{m})$ is relatively enriched in most of the trace elements studied, as compared with the clay fraction and with bulk samples, but the difference between the intermediate fraction and bulk sample composition is smaller than that at Site 482 . We have not detected any clear trend toward increasing concentration in the fraction just above basement or intercalated within basalt. In fact, the average values of most trace elements are approximately equal to or even lower (B, $\mathrm{Zn}, \mathrm{Ag}$ ) than those for sediments recovered far above the basement or from corresponding levels within or immediately overlying the basement at Site 482. Vanadium alone regularly increases with depth in the clay fraction relative to the intermediate fraction.

The highest concentrations in the $2-20 \mu \mathrm{m}$ fraction of zinc along with copper, nickel, and vanadium were detected in three samples from Cores 483-9 through 12 (70$100 \mathrm{~m}$ sub-bottom). Smear slides show that all these samples contain abundant pyrite. The maximum amounts of $\mathrm{Zn}(748 \mathrm{ppm}), \mathrm{Cu}$ (300 ppm), Ni (145 ppm), and V (160 ppm), as well as B (110 ppm), Co (18 ppm), Cr (71 $\mathrm{ppm})$, and $\mathrm{Pb}(74 \mathrm{ppm})$ were determined in a sample of 
Table 5. Trace element composition of sediments, Site 482 .

\begin{tabular}{lcccccccccccccccc}
\hline $\begin{array}{c}\text { Sample } \\
\text { (interval in } \mathrm{cm})\end{array}$ & $\begin{array}{c}\text { Sub-bottom } \\
\text { Depth }(\mathrm{m})\end{array}$ & $\mathrm{B}$ & $\mathrm{Co}$ & $\mathrm{Cr}$ & $\mathrm{Cu}$ & $\mathrm{Mo}$ & $\mathrm{Ni}$ & $\mathrm{V}$ & $\mathrm{Pb}$ & $\mathrm{Sn}$ & $\mathrm{Zn}$ & $\mathrm{Ag}$ & $\mathrm{Sc}$ & $\mathrm{Zr}$ \\
\hline Bulk samples & &
\end{tabular}

Hole 482A

$\begin{array}{lrrrrrrrrrrrr}\text { 3-1, 103-106 } & 16.63 & 95 & 7 & 55 & 41 & 25 & 44 & 75 & 38 & 3 & 115 & 0.32 \\ \text { Hole } 482 \mathrm{~B} & & & & & & & & & & & & \\ 2-2,88-90 & 55.88 & 71 & 9 & 56 & 50 & 33 & 59 & 76 & 36 & 4 & 138 & 0.35 \\ 7-2,94-96 & 103.44 & 65 & 6 & 30 & 37 & 22 & 32 & 56 & 25 & 2 & 120 & 0.19 \\ 9-6,118-120 & 128.68 & 58 & 8 & 38 & 51 & 16 & 50 & 73 & 33 & 4 & 148 & 0.25 \\ 10-4,42-46 & 134.42 & 76 & 10 & 48 & 66 & 37 & 63 & 80 & 46 & 5 & 270 & 0.29 \\ 10-5,102-104 & 136.52 & 67 & 8 & 46 & 58 & 19 & 59 & 85 & 38 & 4 & 152 & 0.21 \\ 10-7,4-6^{\mathrm{a}} & 138.54 & 56 & 10 & 48 & 55 & 18 & 50 & 81 & 42 & 4 & 178 & 0.23 \\ 19-1,47-49^{\mathrm{b}} & 193.47 & 51 & 7 & 40 & 46 & 7 & 40 & 67 & 36 & 3 & 142 & 0.25 \\ \text { Hole } 482 \mathrm{C} & & & & & & & & & & & & \\ 7-6,25-27 & 128.25 & 62 & 10 & 50 & 55 & 19 & 62 & 81 & 44 & 4 & 190 & 0.32 \\ 9-1,12-14^{\mathrm{a}} & 132.12 & 40 & 8 & 35 & 43 & 13 & 48 & 68 & 32 & 3 & 160 & 0.25 \\ \text { Hole } 482 \mathrm{D} & & & & & & & & & & & & \\ 1-4,120-123 & 77.20 & 112 & 7 & 48 & 43 & 18 & 50 & 77 & 28 & 3 & 135 & 0.29 \\ 5-2,60-63 & 11.60 & 72 & 9 & 55 & 45 & 22 & 50 & 87 & 46 & 4 & 126 & 0.32 \\ 7-3,145-147^{\mathrm{a}} & 132.95 & 56 & 11 & 53 & 37 & 25 & 63 & 93 & 50 & 5 & 174 & 0.29 \\ 9-1,5-7^{\mathrm{b}} & 141.53 & 51 & 9 & 44 & 46 & 18 & 49 & 82 & 38 & 4 & 195 & 0.27\end{array}$

Hole $482 \mathrm{~F}$

\begin{tabular}{|c|c|c|c|c|c|c|c|c|c|c|c|c|}
\hline $3-4,88-90$ & 128.38 & 65 & 10 & 40 & 44 & 16 & 44 & 77 & 33 & 3 & 148 & 0.25 \\
\hline $4-2,38-40$ & 133.88 & 65 & 8 & 43 & 48 & 18 & 50 & 84 & 36 & 3 & 195 & 0.23 \\
\hline $4-3,46-49$ & 135.46 & 62 & 8 & 40 & 46 & 15 & 48 & 81 & 33 & 3 & 142 & 0.23 \\
\hline $4-3,100-102^{a}$ & 136.00 & 32 & 8 & 41 & 45 & 15 & 55 & 80 & 28 & 3 & 138 & 0.19 \\
\hline \multicolumn{13}{|l|}{ Average: } \\
\hline \multicolumn{2}{|c|}{$\begin{array}{l}\text { Sediments above } \\
\text { basement }(n=12)\end{array}$} & 72 & 8 & 46 & 49 & 22 & 51 & 78 & 36 & 4 & 157 & 0.27 \\
\hline \multicolumn{2}{|c|}{$\begin{array}{l}\text { Sediments just above } \\
\text { basement }(n=4)\end{array}$} & 46 & 9 & 44 & 45 & 18 & 54 & 80 & 38 & 4 & 162 & 0.24 \\
\hline \multicolumn{2}{|c|}{$\begin{array}{l}\text { Sediments intercalated within } \\
\text { basalts }(n=2)\end{array}$} & 51 & 8 & 42 & 46 & 12 & 44 & 74 & 37 & 4 & 168 & 0.26 \\
\hline
\end{tabular}

2-20 $\mu \mathrm{m}$ sediment fraction

Hole $482 \mathrm{~A}$

$\begin{array}{lrrrrrrrrrrrr}\begin{array}{l}3-1,103-106 \\ \text { Hole } 482 \mathrm{~B}\end{array} & 16.63 & 62 & 8 & 54 & 170 & 40 & 45 & 91 & 59 & 12 & 125 & 2.9 \\ 2-2,89-90 & & & & & & & & & & & & \\ 7-2,94-96 & 103.44 & 63 & 8 & 62 & 138 & 48 & 61 & 88 & 50 & 5 & 230 & 1.8 \\ 9-6,118-120 & 128.68 & 63 & 11 & 48 & 240 & 60 & 48 & 75 & 63 & 8 & 300 & 3.3 \\ 10-4,42-44 & 134.42 & 58 & 9 & 40 & 186 & 29 & 75 & 96 & 60 & 11 & 325 & 2.0 \\ 10-5,102-104 & 136.52 & 95 & 21 & 92 & 850 & 5 & 163 & 160 & 63 & 8 & 343 & 2.9 \\ 10-7,4-6^{\mathrm{a}} & 138.54 & 70 & 16 & 61 & 380 & 39 & 110 & 113 & 83 & 14 & 576 & 5.0 \\ 19-1,47-49^{\mathrm{b}} & 193.47 & 93 & 21 & 91 & 350 & 21 & 97 & 148 & 95 & 29 & 638 & 4.6\end{array}$

Hole $482 \mathrm{C}$

$\begin{array}{lllllllllllll}7-6,25-27 & 128.25 & 62 & 11 & 42 & 260 & 24 & 69 & 85 & 72 & 14 & 338 & 4.4 \\ 9-1,12-14^{\mathrm{a}} & 132.12 & 65 & 12 & 53 & 290 & 26 & 86 & 94 & 68 & 10 & 315 & 4.7\end{array}$

Hole 482D

$\begin{array}{lrrrrrrrrrrrr}1-4,120-123 & 77.20 & 114 & 11 & 67 & 229 & 40 & 69 & 115 & 63 & 8 & 282 & 4.0 \\ 5-2,60-63 & 111.60 & 63 & 11 & 54 & 186 & 33 & 58 & 86 & 59 & 9 & 308 & 2.3 \\ 7-3,145-147^{a} & 132.95 & 59 & 13 & 47 & 154 & 28 & 85 & 97 & 72 & 8 & 274 & 2.8 \\ 9-1,5-7^{b} & 141.53 & 69 & 14 & 50 & 286 & 29 & 90 & 101 & 80 & 14 & 404 & 6.6\end{array}$

Hole $482 \mathrm{~F}$

$\begin{array}{lllllllllllll}3-4,88-90 & 128.38 & 61 & 12 & 43 & 190 & 35 & 61 & 89 & 69 & 7 & 245 & 2.0 \\ 4-3,46-49 & 135.46 & 51 & 11 & 54 & 138 & 28 & 73 & 87 & 55 & 6 & 270 & 2.2 \\ 4-3,100-102^{a} & 136.00 & 57 & 13 & 48 & 197 & 28 & 77 & 90 & 71 & 6 & 384 & 5.3\end{array}$

Average:

$\begin{array}{llllllllllll}\begin{array}{l}\text { Sediments above } \\ \text { basement }(n=11)\end{array} & 66 & 10 & 52 & 192 & 38 & 62 & 89 & 61 & 9 & 277 & 2.8\end{array}$

$\begin{array}{llllllllllll}\text { basement }(n=11) & & & & & & & & \\ \text { Sediments immediately overlying } & 63 & 14 & 52 & 255 & 30 & 90 & 99 & 74 & 10 & 387 & 4.5\end{array}$

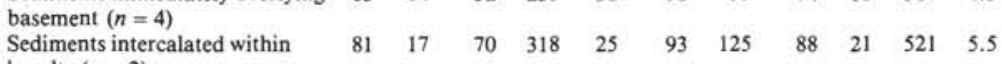

basalts $(n=2)$

Clay sediment fraction

Hole 482A

3-1, 103-106

16.63

$\begin{array}{lllll}27 \quad 120 & 23 \quad 110 \quad 20 \quad-\end{array}$

14200 
Table 5. (Continued).

\begin{tabular}{|c|c|c|c|c|c|c|c|c|c|c|c|c|c|c|}
\hline $\begin{array}{c}\text { Sample } \\
\text { (interval in cm) }\end{array}$ & $\begin{array}{l}\text { Sub-bottom } \\
\text { Depth }(\mathrm{m})\end{array}$ & B & Co & $\mathrm{Cr}$ & $\mathrm{Cu}$ & Mo & $\mathrm{Ni}$ & V & $\mathrm{Pb}$ & Sn & $\mathrm{Zn}$ & $\mathrm{Ag}$ & Sc & $\mathrm{Zr}$ \\
\hline \multicolumn{15}{|c|}{ Clay sediment fraction (Cont.) } \\
\hline \multicolumn{15}{|l|}{ Hole 482B } \\
\hline $2-2,88-90$ & 55.88 & & - & 95 & 87 & & 16 & 90 & 14 & - & & & 15 & 118 \\
\hline $7-2,94-96$ & 103.44 & & 8 & 45 & 190 & & 18 & 86 & 16 & 2 & & & 23 & 110 \\
\hline $9-6,118-120$ & 128.68 & & 11 & 65 & 100 & & 22 & 100 & 9 & 2 & & & 28 & 118 \\
\hline $10-4,42-44$ & 134.42 & & - & 120 & 68 & & 24 & 100 & 17 & - & & & 13 & 165 \\
\hline $10-5,102-104$ & 136.52 & & - & 27 & 84 & & 14 & 63 & 13 & - & & & 8 & 148 \\
\hline $10-7,4-6$ & 138.54 & & 5 & 36 & 100 & & 16 & 71 & 15 & 2 & & & 12 & 93 \\
\hline $19-1,47-49$ & 193.47 & & - & 68 & 95 & & 20 & 85 & 15 & - & & & 16 & 135 \\
\hline \multicolumn{15}{|l|}{ Hole $482 \mathrm{C}$} \\
\hline $7-6,25-27$ & 128.25 & & - & 200 & 120 & & 45 & 240 & 15 & - & & & 30 & 180 \\
\hline $9-1,12-14$ & 132.12 & & - & 140 & 200 & & 22 & 156 & 16 & 3 & & & 14 & 170 \\
\hline \multicolumn{15}{|l|}{ Hole 482D } \\
\hline $1-4,120-123$ & 77.20 & & - & 166 & 150 & & so & 116 & 17 & 4 & & & 22 & 120 \\
\hline $5-2,60-63$ & 111.60 & & - & 112 & 62 & & 42 & 93 & 10 & 4 & & & 12 & 115 \\
\hline $7-3,145-147$ & 132.95 & & - & 93 & 64 & & 22 & 140 & 9 & - & & & 19 & 140 \\
\hline $9-1,3-7$ & 141.53 & & - & 220 & 107 & & 56 & 165 & 24 & - & & & 18 & 65 \\
\hline \multicolumn{15}{|l|}{ Hole $482 \mathrm{~F}$} \\
\hline $3-4,88-90$ & 128.38 & & - & 87 & 65 & & 50 & 70 & 38 & - & & & 15 & 190 \\
\hline $4-2,38-40$ & 133.88 & & 12 & 170 & 118 & & 40 & 160 & 4 & - & & & 20 & 250 \\
\hline $4-3,41-49$ & 135.46 & & - & 130 & 130 & & 60 & 125 & 12 & 7 & & & 27 & 135 \\
\hline $4-3,100-102$ & 136.00 & & - & 130 & 106 & & 50 & 100 & 12 & 4 & & & 19 & 138 \\
\hline \multicolumn{15}{|l|}{ Average: } \\
\hline \multicolumn{4}{|c|}{$\begin{array}{l}\text { Sediments above basement } \\
(n=12)\end{array}$} & 104 & 108 & & 34 & 113 & 15 & 4 & & & 19 & 154 \\
\hline \multicolumn{4}{|c|}{$\begin{array}{l}\text { Sediments immediately overlying } \\
\text { basement }(n=4)\end{array}$} & 100 & 118 & & 28 & 117 & 13 & 3 & & & 16 & 135 \\
\hline \multicolumn{3}{|c|}{$\begin{array}{l}\text { Sediments intercalated within } \\
\text { basalts }(n=2)\end{array}$} & & 144 & 101 & & 38 & 125 & 20 & & & & 17 & 100 \\
\hline
\end{tabular}

Note: Values shown in ppm.

a Sediments just above basement.

b Sediments intercalated within basalts

$-=$ Not detected.

silty clay with about $6 \%$ pyrite (Sample 483-12-3, 88-90 $\mathrm{cm})$. In this sample we found also barite and ankerite; small sphaelerite(?) crystals may be present.

\section{SITE 484}

The holes at Site 484 were drilled on a basement "diapir" that was covered by 50 meters of thick upper Quaternary hemipelagic mud. The sedimentation rate is about $110 \mathrm{~m} / \mathrm{m} . \mathrm{y}$. We studied four samples from Hole $484 \mathrm{~A}$. The lowermost sample, 484A-6-5, 23-25 cm, was taken within 3 meters of the basement.

\section{Mineralogy}

The mineralogy of the sediments, as determined in smear slides, differs from that at Sites 482 and 483 by higher biogenic opal content and by less abundant terrigenous quartz and feldspars. The upper three samples studied (Section 3 in Cores 1, 3, and 6) are siliceous clay, siliceous silty clay, and nannofossil ooze, respectively, whereas Sample 484A-6-5, 23-25 cm, taken just above basement, contains only a minor admixture of poorly preserved (dissolved?) radiolarians. In this sample we observed irregular aggregates of an opal-like mineral, possibly authigenic opal, formed after biogenic silica dissolution. Pyrite content is low (commonly less than $1 \%$ ). In all samples we found authigenic carbonates (dolomite-ankerite?), zeolite, and rare barite. Biogenic phosphate occurs sporadically.
X-ray diffraction data (Table 8) show that the mineralogy of the clay fraction is similar to that in Holes $482 \mathrm{~A}$ and $482 \mathrm{~B}$. Smectite strongly predominates over mica with minor admixtures of chlorite and kaolinite. In coarser fractions, smectite content is much lower-equal to or even less than that of mica. Only in the lowermost sample does smectite predominate. Clinoptilolite was detected in the clay and intermediate fractions of all samples. In the three upper samples of the $2-20 \mu \mathrm{m}$ fraction, it is abundant.

A single coarse fraction analysis of Sample 484-6-5, $23-25 \mathrm{~cm}$ (just above basement) shows $2.4 \%$ heavy minerals, $93 \%$ of which consists of pyrite. The rest are hornblende, epidote, zircon, and apatite. The light fraction is composed of almost equal amounts of quartz and feldspars with abundant aggregates and pellets of clay. Zeolite was not found in this fraction.

\section{Geochemistry}

Bulk analyses of two samples (Table 9) show that sediments near the basalts and far above are chemically quite similar, resembling those in the upper part of the section at Site 482 . The $2-20 \mu \mathrm{m}$ fraction is more enriched in $\mathrm{SiO}_{2}, \mathrm{CaO}$, and $\mathrm{Na}_{2} \mathrm{O}$, whereas $\mathrm{Al}_{2} \mathrm{O}_{3}, \mathrm{FeO}$, $\mathrm{MgO}$, and the $\mathrm{K}_{2} \mathrm{O}$ to $\mathrm{Na}_{2} \mathrm{O}$ ratio tend to increase in the clay fraction. The $\mathrm{SiO}_{2}$ to $\mathrm{Al}_{2} \mathrm{O}_{3}$ ratio is somewhat higher in the coarse fraction as a result of its more abundant biogenic silica, and the $\mathrm{Al}$ to $\mathrm{Ti}$ ratio is close to that of average terrigenous matter. 
Table 6. Mineralogy of the $2-20 \mu \mathrm{m}$ and clay sediment fractions, Site 483 (in percent).

\begin{tabular}{|c|c|c|c|c|c|c|c|c|c|c|c|c|}
\hline $\begin{array}{l}\text { Sample } \\
\text { (interval in } \mathrm{cm} \text { ) }\end{array}$ & $\begin{array}{l}\text { Sub-bottom } \\
\text { Depth } \\
\text { (m) }\end{array}$ & Lithology & Age & Smectite & Mica & Chlorite & $\begin{array}{c}\text { Mixed-layer } \\
\text { Chlorite- } \\
\text { Montmorillonite }\end{array}$ & $\mathrm{Z}$ & Quartz & Clinoptilolite & $\begin{array}{l}\text { Amorphous } \\
\text { Phase }\end{array}$ & Feldspar \\
\hline \multicolumn{13}{|c|}{ Intermediate $(2-20 \mu \mathrm{m})$ sediment fraction } \\
\hline \multicolumn{13}{|l|}{ Hole 483} \\
\hline $2-3,10-12$ & 4.10 & Unit II & Upper Quaternary & 20 & 70 & 10 & & 0.6 & d & c & c & d \\
\hline $5-3,131-133$ & 33.81 & $\begin{array}{l}\text { Diatomaceous mud and ooze, } \\
\text { muddy nannofossil ooze }\end{array}$ & 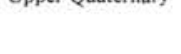 & 45 & 45 & 10 & & 0.7 & d & c & c & d \\
\hline $7-5,90-92$ & 55.40 & & & 58 & 36 & 6 & $\operatorname{tr}$ & 0.6 & d & c & c & c \\
\hline $9-2,60-62$ & 69.60 & Unit III & Lower Quaternary & 75 & 20 & 5 & tr & 0.6 & c & c & tr & c \\
\hline $10-2,5-8$ & 78.55 & Clay and silty clay & & 57 & 36 & 7 & tf & 0.6 & c & c & tr & c \\
\hline $11-4,110-113$ & 92.10 & & & 60 & 22 & 8 & & 0.6 & c & d & tr & c \\
\hline $12-3,88-90$ & 99.80 & & & 70 & 24 & 6 & tr & 0.6 & d & d & tr & $\begin{array}{c}c \\
d\end{array}$ \\
\hline $13-1,120-122$ & 106.70 & & & 58 & 34 & 8 & tr & 0.7 & d & d & c & d \\
\hline $13-2,110-112$ & 108.10 & & & 69 & 25 & 6 & tr & 0.7 & $\begin{array}{c}\text { d } \\
c\end{array}$ & c & $\operatorname{tr}$ & $\begin{array}{c}c \\
\text { d }\end{array}$ \\
\hline $13-3,50-52$ & 109.00 & & & 59 & 35 & 6 & tr & 0.7 & d & c & & d \\
\hline $18-2,55-57^{b}$ & 153.05 & Silty clay, siltstone, & Upper Pliocene & 56 & 29 & 15 & tr & 0.7 & $d$ & & tr & c \\
\hline $18-4,63-65^{b}$ & 156.13 & and claystone & & 68 & 18 & 14 & tr & 0.6 & d & & tr & \\
\hline \multicolumn{13}{|l|}{ Hole 483B } \\
\hline $2-6,93-97^{a}$ & 109.43 & $\begin{array}{l}\text { Unit I } \\
\text { Silty clay }\end{array}$ & Quaternary & 54 & 38 & 8 & & 0.7 & d & d & tr & d \\
\hline \multicolumn{13}{|c|}{ Clay sediment fraction } \\
\hline \multicolumn{13}{|l|}{ Hole 483} \\
\hline $2-3,10-12$ & 4.10 & Unit I & Upper Quaternary & 68 & 24 & 8 & ts & 0.4 & tr & c & tr & tr \\
\hline $5-3,131-133$ & 33.81 & Diatomaceous mud and ooze, & & 71 & 23 & 6 & & 0.4 & tr & $\mathrm{c}$ & tr & tr \\
\hline $7-5,90-92$ & 55.40 & muddy nannofossil ooze & & 75 & 13 & 12 & & 0.6 & tr & $\mathrm{c}$ & tr & tr \\
\hline $9-2,60-62$ & 69.60 & Unit III & & 79 & 16 & 5 & tr & 0.5 & tr & $\mathrm{c}$ & tr & tr \\
\hline $10-2,5-8$ & 78.55 & Clay and silty clay & Lower Quaternary & 70 & 21 & 9 & & 0.5 & tr & $\mathrm{c}$ & tr & tr \\
\hline $11-4,110-113$ & 92.10 & & & 78 & 18 & 4 & tr & 0.5 & tr & $\mathrm{c}$ & tr & tr \\
\hline $12-3,88-90$ & 99.80 & & & 57 & 38 & 5 & tr & 0.3 & tr & $\mathrm{c}$ & tr & tr \\
\hline $13-1,120-122$ & 106.70 & & & 75 & 19 & 6 & & 0.5 & tr & $\mathrm{c}$ & tr & tr \\
\hline $13-2,110-112$ & 108.10 & & & 75 & 23 & 2 & & 0.5 & tr & c & tr & tr \\
\hline $13-3,50-52$ & 109.00 & & & 84 & 14 & 2 & & 0.6 & tr & & tr & tr \\
\hline $18-2,55-57^{b}$ & 153.05 & & & 73 & 19 & 8 & & 0.5 & tr & & tr & tr \\
\hline $18-4,63-65^{b}$ & 156.13 & $\begin{array}{l}\text { Silty clay, siltstone, } \\
\text { and claystone }\end{array}$ & Upper Pliocene & 78 & 15 & 7 & & 0.5 & tr & & tr & tr \\
\hline \multicolumn{13}{|l|}{ Hole 483B } \\
\hline $2-6,93-97^{a}$ & 109.43 & $\begin{array}{l}\text { Unit I } \\
\text { Silty clay }\end{array}$ & Quaternary & 78 & 15 & 7 & & 0.4 & tr & c & tr & tr \\
\hline
\end{tabular}

a Sediment immediately overlying basement.

b Sediments intercalated within basalts.

d Moderate.

Trace elements in the three upper samples (Table 10) occur approximately in the same concentrations as in sediments far above the basement at Site 482 . But in Sample 484A-6-5, 23-25 cm (just above basement) concentrations of most elements (except for $\mathrm{Cr}$, Mo, and $\mathrm{Sn})$, both in bulk samples and particularly in the $2-20 \mu \mathrm{m}$ fraction, are markedly higher. $\mathrm{Zn}, \mathrm{Ag}, \mathrm{Cu}, \mathrm{V}, \mathrm{Ni}, \mathrm{B}$, and Co concentrations in this sample are close to those in most enriched samples from Site 483 and to those from sediments in the basement at Site 482 .

\section{SITE 485}

Site 485 is located about $10 \mathrm{~km}$ southeast of Site 482 on Quaternary crust overlain by 150 meters of lower and upper Quaternary hemipelagic clay mixed with clayey silt and silty sand in the lower part of the section. The site, located near the continental slope of mainland Mexico, is characterized by an extremely high sedimentation rate, about $625 \mathrm{~m} / \mathrm{m}$.y. Several layers of lower Quaternary sediments were recovered intercalated within basalts in the depth interval from 160 to 330 meters sub-bottom, including lithified clayey siltstones, sandstones, and claystones. High heat-flow values were measured at the site.

We studied sediments from Holes 485 and 485A. In the latter, 18 samples are from layers intercalated within basalts, and one sample (485A-11-3, 35-37 cm) was taken $20 \mathrm{~cm}$ above the sediment/basalt contact.

\section{Mineralogy}

The mineralogy of Site 485 sediments, as determined by smear-slide and thin-section analysis, is similar to that at the other sites drilled on Leg 65 . Terrigenous clay minerals and silt-size quartz and feldspars predominate throughout the section, including the sediment layers within basement. Minor biogenic minerals-opal (diatoms, radiolarians, sponge spicules) and calcite (foraminifers, nannofossils) - are unevenly distributed throughout the section. Diatoms and radiolarians are relatively abundant in the upper Quaternary sediments (Hole 485, Cores 1 through 6). Below 50 meters sub-bottom they become rare, and they virtually disappear below $80 \mathrm{me}-$ ters. Biogenic calcite occurs throughout, but high concentrations were found only in several samples from layers intercalated within basement (Hole 485A, Cores $20,22,36$ ). We detected these authigenic minerals in sediments: pyrite, zeolite (clinoptilolite), carbonates (dolomite-ankerite), barite, gypsum, and opal(?).

Pyrite occurs throughout the section. In the upper portion of the section above the basalts, pyrite content is commonly low, about $1 \%$ or less, according to visual estimation in smear slides. It is represented mainly by 
Table 7. Trace element composition of sediments, Site 483 .

\begin{tabular}{lllllllllllllllllll}
\hline $\begin{array}{c}\text { Sample } \\
\text { (interval in cm) }\end{array}$ & $\begin{array}{c}\text { Sub-bottom } \\
\text { Depth }(\mathrm{m})\end{array}$ & B & $\mathrm{Co}$ & $\mathrm{Cr}$ & $\mathrm{Cu}$ & $\mathrm{Mo}$ & $\mathrm{Ni}$ & $\mathrm{V}$ & $\mathrm{Pb}$ & $\mathrm{Sn}$ & $\mathrm{Zn}$ & $\mathrm{Ag}$ & $\mathrm{Sc}$ & $\mathrm{Zr}$ \\
\hline
\end{tabular}

Coarse sediment

Hole 483

$\begin{array}{lrrrrrrrrrrrr}2-3,10-12 & 4.10 & 102 & 17 & 62 & 119 & 19 & 118 & 104 & 55 & 3 & 250 & 0.32 \\ 5-3,131-133 & 33.81 & 107 & 15 & 50 & 112 & 82 & 85 & 83 & 50 & 3 & 210 & 0.37 \\ 9-2,60-62 & 69.60 & 115 & 19 & 63 & 144 & 24 & 167 & 118 & 56 & 4 & 440 & 0.45 \\ 11-4,110-113 & 92.10 & 110 & 15 & 50 & 97 & 10 & 116 & 108 & 38 & 3 & 265 & 0.29 \\ 12-3,88-90 & 99.80 & 110 & 18 & 56 & 125 & 9 & 161 & 126 & 46 & 3 & 310 & 0.48 \\ 13-1,120-122 & 106.70 & 100 & 14 & 62 & 76 & 25 & 114 & 108 & 50 & 4 & 215 & 0.29 \\ 13-3,50-52^{\mathrm{a}} & 109.00 & 72 & 11 & 46 & 87 & 10 & 119 & 96 & 40 & 3 & 230 & 0.45 \\ 18-2,55-57^{\mathrm{b}} & 153.05 & 87 & 9 & 50 & 55 & 11 & 50 & 90 & 42 & 4 & 142 & 0.27 \\ 18-4,63-65^{\mathrm{b}} & 156.13 & 107 & 11 & 56 & 68 & 12 & 90 & 85 & 40 & 4 & 158 & 0.35\end{array}$

Hole 483B

$\begin{array}{lccccccccccc}2-6,93-97^{\mathrm{a}} \quad 109.43 & 95 & 12 & 44 & 84 & 19 & 82 & 101 & 40 & 3 & 174 & 0.29 \\ \begin{array}{l}\text { Average: } \\ \begin{array}{l}\text { Sediments above basement } \\ (n=6)\end{array}\end{array} & 107 & 16 & 57 & 112 & 28 & 127 & 108 & 49 & 3 & 282 & 0.37 \\ \begin{array}{l}\text { Sediments just above } \\ \text { basement }(n=2)\end{array} & 83 & 11 & 45 & 85 & 14 & 100 & 98 & 40 & 3 & 202 & 0.37 \\ \begin{array}{l}\text { Sediments intercalated within } \\ \text { basalts }(n=2)\end{array} & 97 & 10 & 53 & 62 & 11 & 70 & 87 & 41 & 4 & 150 & 0.31\end{array}$

2-20 $\mu \mathrm{m}$ sediment fraction

Hole 483

$\begin{array}{lr}2-3,10-12 & 4.10 \\ 5-3,131-133 & 33.81 \\ 9-2,60-62 & 69.60 \\ 11-4,110-113 & 92.10 \\ 12-3,88-90 & 99.80 \\ 13-1,120-122 & 106.70 \\ 13-3,50-52^{\mathrm{a}} & 109.00 \\ 18-2,55-57^{\mathrm{b}} & 153.05 \\ 18-4,63-65^{\mathrm{b}} & 156.13\end{array}$

$\begin{array}{rrrrrrrrrrr}42 & 11 & 26 & 179 & 45 & 47 & 71 & 40 & 8 & 353 & 4.6 \\ 48 & 9 & 28 & 260 & 52 & 49 & 62 & 44 & 24 & 453 & 6.0 \\ 67 & 12 & 33 & 200 & 5 & 92 & 92 & 40 & 9 & 605 & 3.8 \\ 63 & 11 & 37 & 215 & 12 & 104 & 97 & 60 & 8 & 633 & 4.5 \\ 110 & 18 & 71 & 300 & 7 & 145 & 160 & 74 & 12 & 748 & 3.8 \\ 54 & 8 & 37 & 120 & 105 & 43 & 81 & 42 & 9 & 260 & 4.4 \\ 50 & 9 & 37 & 170 & 12 & 79 & 80 & 52 & 13 & 470 & 4.1 \\ 51 & 11 & 48 & 200 & 12 & 40 & 87 & 46 & 14 & 303 & 3.8 \\ 63 & 11 & 53 & 230 & 28 & 73 & 92 & 72 & 6 & 328 & 4.0\end{array}$

Hole 483B

$\begin{array}{llllllllllllll}2-6,93-97^{\mathrm{a}} & 109.43 & 44 & 7 & 30 & 81 & 32 & 46 & 67 & 36 & 8 & 158 & 1.8\end{array}$

Average:

Sediments above basement

$(n=6)$

Sediments just above

basement $(n=2)$

Sediments intercalated within

basalts $(n=2)$

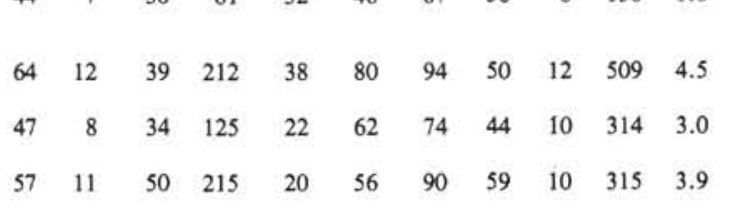

\section{Clay sediment fraction}

Hole 483

\begin{tabular}{|c|c|c|c|c|c|c|c|c|c|c|c|c|c|c|}
\hline $2-3,10-12$ & 4.10 & & & 1 & 48 & & 58 & 150 & - & & & & 6 & 100 \\
\hline $5-3,131-133$ & 33.81 & 160 & 47 & 36 & 54 & 34 & 54 & 110 & 9 & 5 & 110 & 8.4 & 8 & 120 \\
\hline $9-2,60-62$ & 69.60 & & & 56 & 65 & & 79 & 220 & 21 & & & & 11 & 153 \\
\hline $11-4,110-113$ & 92.10 & & & 48 & 69 & & 72 & 150 & 14 & & & & 10 & 178 \\
\hline $13-1,120-122$ & 106.70 & & & 60 & 42 & & 39 & 100 & 6 & & & & 12 & 118 \\
\hline $13-3,50-52^{\mathrm{a}}$ & 109.00 & 66 & 15 & 52 & 60 & 12 & 85 & 140 & 12 & 6 & 380 & 8.0 & 17 & 110 \\
\hline $18-2,55-57^{b}$ & 153.05 & & & 150 & 100 & & 40 & 140 & 13 & & & & 18 & 105 \\
\hline $18-4,63-65^{b}$ & 156.13 & 99 & 13 & 90 & 70 & 16 & 45 & 95 & 9 & 5 & 340 & 5.5 & 14 & 93 \\
\hline \multicolumn{15}{|l|}{ Hole 483B } \\
\hline $2-6,93-97^{a}$ & 109.43 & & & 75 & 55 & & 49 & 200 & 15 & & & & 18 & 138 \\
\hline \multicolumn{15}{|l|}{ Average: } \\
\hline \multicolumn{2}{|c|}{$\begin{array}{l}\text { Sediments above basement } \\
(n=5)\end{array}$} & & & 50 & 56 & & 60 & 146 & 12 & & & & 9 & 134 \\
\hline \multicolumn{2}{|c|}{$\begin{array}{l}\text { Sediments just above } \\
\text { basement }(n=2)\end{array}$} & & & 64 & 57 & & 67 & 170 & 14 & & & & 18 & 124 \\
\hline \multicolumn{2}{|c|}{$\begin{array}{l}\text { Sediments intercalated within } \\
\text { basalts }(n=2)\end{array}$} & & & 120 & 85 & & 42 & 117 & 11 & & & & 16 & 99 \\
\hline
\end{tabular}

Note: Values shown in ppm.

a Sediments just above basement.

b Sediments intercalated within basalts.

$-=$ Not detected. 
Table 8. Mineralogy of clay and intermediate sediment fractions, Site 484 (in percent).

\begin{tabular}{|c|c|c|c|c|c|c|c|c|c|c|c|c|}
\hline $\begin{array}{c}\text { Sample } \\
\text { (interval in cm) }\end{array}$ & $\begin{array}{l}\text { Sub-bottom } \\
\text { Depth } \\
\text { (m) }\end{array}$ & Lithology & Age & Smectite & Mica & Chlorite & $\begin{array}{c}\text { Mixed-layer } \\
\text { Chlorite- } \\
\text { Montmorillonite }\end{array}$ & $\mathrm{Z}$ & Quartz & Clinoptilolite & $\begin{array}{l}\text { Amorphous } \\
\text { Phase }\end{array}$ & Feldspar \\
\hline \multicolumn{13}{|c|}{ Clay $(<2 \mu \mathrm{m})$ sediment fraction } \\
\hline \multicolumn{13}{|l|}{ Hole $484 \mathrm{~A}$} \\
\hline $1-3,130-134$ & 4.30 & $\begin{array}{l}\text { Unit I } \\
\text { Siliceous clay }\end{array}$ & Upper Quaternary & 78 & 14 & 8 & & 0.5 & tr & b & tr & tr \\
\hline $3-3,110-114$ & 21.60 & Unit II & & 65 & 27 & 8 & tr & 0.3 & tr & b & tr & tr \\
\hline $6-3,110-114$ & 50.10 & Siliceous silty clay, clayey & & 74 & 18 & 8 & tr & 0.4 & tr & b & tr & tr \\
\hline $6-5,23-25$ & $52.23^{\mathrm{a}}$ & $\begin{array}{l}\text { siliceous ooze and } \\
\text { nannofossil ooze }\end{array}$ & & 65 & 26 & 9 & tr & 0.6 & tr & b & tr & tr \\
\hline \multicolumn{13}{|c|}{ Intermediate $(2-20 \mu \mathrm{m})$ sediment fraction } \\
\hline \multicolumn{13}{|l|}{ Hole $484 \mathrm{~A}$} \\
\hline $1-3,130-134$ & 4.30 & $\begin{array}{l}\text { Unit I } \\
\text { Siliceous clay }\end{array}$ & Upper Quaternary & 48 & 48 & 4 & tr & 0.7 & c & c & b & c \\
\hline $3-3,110-114$ & 21.60 & Unit II & & 42 & 52 & 6 & tr & 0.7 & c & c & b & c \\
\hline $6-3,110-114$ & 50.10 & Siliceous silt clay, clayey & & 45 & 45 & 10 & tr & 0.7 & c & c & b & c \\
\hline $6-5,23-25$ & $52.23^{\mathrm{a}}$ & $\begin{array}{l}\text { siliceous ooze and } \\
\text { nannofossil ooze }\end{array}$ & & 66 & 29 & 5 & $\mathrm{tr}$ & 0.5 & b & b & tr & b \\
\hline
\end{tabular}

a Sediments just above basement.

b Moderate.

c Abundant.

d $\mathrm{Tr}=$ trace.

Table 9. Chemical composition of sediments, Hole 484A.

\begin{tabular}{|c|c|c|c|c|c|c|}
\hline \multirow[b]{3}{*}{ Component } & \multicolumn{6}{|c|}{$\begin{array}{l}\text { Sample } \\
\text { (interval in } \mathrm{cm} \text { ) }\end{array}$} \\
\hline & \multicolumn{3}{|c|}{$484 \mathrm{~A}-1-3,130-134$} & \multicolumn{3}{|c|}{$484 \mathrm{~A}-6-5,23-25^{\mathrm{a}}$} \\
\hline & Bulk & $2-20 \mu \mathrm{m}$ & $<2 \mu \mathrm{m}$ & Bulk & $2-20 \mu \mathrm{m}$ & $<2 \mu \mathrm{m}$ \\
\hline $\mathrm{SiO}_{2}$ & 52.94 & 65.84 & 54.30 & 50.10 & 61.96 & 54.90 \\
\hline $\mathrm{TiO}_{2}^{2}$ & 0.51 & 0.51 & 0.60 & 0.51 & 0.54 & 0.62 \\
\hline $\mathrm{Al}_{2} \mathrm{O}_{3}$ & 12.95 & 13.61 & 15.96 & 13.56 & 14.33 & 15.99 \\
\hline $\mathrm{Fe}_{2} \mathrm{O}_{3}$ & 3.31 & 2.97 & 3.80 & 3.87 & 3.40 & 3.24 \\
\hline $\mathrm{FeO}$ & 1.46 & 0.87 & 1.67 & 1.02 & 0.80 & 1.34 \\
\hline $\mathrm{MnO}$ & 0.11 & 0.07 & 0.07 & 0.10 & 0.07 & 0.06 \\
\hline $\mathrm{MgO}$ & 2.18 & 1.53 & 2.34 & 2.18 & 2.01 & 2.90 \\
\hline $\mathrm{CaO}$ & 5.15 & 1.79 & 0.89 & 5.60 & 1.45 & 0.34 \\
\hline $\mathrm{Na}_{2} \mathrm{O}$ & 3.20 & 2.25 & 0.98 & 2.83 & 2.09 & 0.94 \\
\hline $\mathrm{K}_{2} \mathrm{O}$ & 2.40 & 2.95 & 2.59 & 2.70 & 3.05 & 2.68 \\
\hline $\mathrm{P}_{2} \mathrm{O}_{5}$ & 0.18 & 0.19 & 0.15 & 0.13 & 0.27 & 0.22 \\
\hline LÖI & 15.10 & 7.10 & 16.60 & 17.30 & 9.90 & 16.10 \\
\hline Total & 99.49 & 99.68 & 99.95 & 99.90 & 99.87 & 99.33 \\
\hline $\mathrm{K}_{2} \mathrm{O} / \mathrm{Na}_{2} \mathrm{O}$ & 0.75 & 1.31 & 2.64 & 0.95 & 1.46 & 2.85 \\
\hline $\mathrm{K}_{2} \mathrm{O}+\mathrm{Na}_{2} \mathrm{O} / \mathrm{Al}_{2} \mathrm{O}_{3}$ & 0.43 & 0.38 & 0.22 & 0.41 & 0.36 & 0.23 \\
\hline $\mathrm{Fe}_{2} \mathrm{O}_{3}+\mathrm{FeO}+\mathrm{MgO} / \mathrm{Al}_{2} \mathrm{O}_{3}$ & 0.54 & 0.39 & 0.49 & 0.52 & 0.43 & 0.47 \\
\hline $\mathrm{SiO}_{2} / \mathrm{Al}_{2} \mathrm{O}_{3}$ & 4.09 & 4.84 & 3.40 & 3.69 & 4.32 & 3.43 \\
\hline $\mathrm{Fe}$ & 3.46 & 2.76 & 3.96 & 3.50 & 3.00 & 3.31 \\
\hline $\mathrm{Al} / \mathrm{Ti}$ & 22.13 & 23.26 & 23.5 & 23.19 & 23.72 & 22.89 \\
\hline
\end{tabular}

Note: Values shown in weight percent.

a Sediment immediately overlying basement.

microspherules several micrometers in diameter. Relatively rich in pyrite $(2 \%)$ are samples from Sections 485-4-2, and 485A-8-2. Abundant pyrite $(3-5 \%)$ was found in some samples from the layers within basement: from Cores 19, 20, 28, 37, 38 of Hole 485A (for sample identification see Table 11). However, in many other samples from those layers intercalated within basalts, pyrite content is rather low: $1 \%$ or less. So the layers do not show any regular increase in pyrite associated with hydrothermal activity. Pyrite occurs as cubic crystals, crystal aggregates, dendritic forms, and as pseudomorphs after fragments of organic material and other sedimentary particles. Spherules are rather rare and some of those show evidence of recrystallization (rounded contours turn into multiangular ones).

Zeolite (clinoptilolite) occurs as platy crystals or irregular grains with clay inclusions in sediments above the uppermost basalt (down to $158 \mathrm{~m}$ sub-bottom). In sediments within basement we found rare colorless grains with a low refractive index, possibly analcime. The mineral is common in Sample 485A-39-1, 94-96 cm, where analcime was identified by $\mathrm{x}$-ray diffraction.

Authigenic carbonates occur as small (1-5 $\mu \mathrm{m}$ or less) rhombohedral crystals and irregular grains. Grains with a high refractive index along both axes seem to be ankerite, whereas those with one index less than 1.54 are likely to be dolomite or calcite. The authigenic carbonates are more abundant in the sediment section above basalts. In some samples their concentration is visually up to $1-2 \%$ (Hole $485 \mathrm{~A}$, Cores $6,9,11$ ). In the layers within basement we found carbonates mainly in trace amounts, most of those being dolomite or calcite.

However, in two samples from Section 485A-2-1, we observed in thin sections spheroidal poikiloblastic crystal aggregates of a carbonate mineral (dolomite?) 0.05 to $0.5 \mathrm{~mm}$ in diameter. The crystals are filled with sediment particles, such as clay minerals, quartz, and plant debris, which show a primary orientation subparallel to bedding. The same samples contain authigenic mixedlayer clay minerals and analcime.

Barite is rare in the sediments at this site. We observed rare crystals of the mineral in a sample from Section 485-3-4 and in several others. In two thin sections from Hole $485 \mathrm{~A}$, Core 20 we found a single barite spherulite in each. In most samples the mineral is absent.

Gypsum was identified with certainty in only one smear slide (Sample 485A-11-2, 107-111 cm), where we observed a "swallow-tail" twin, but most likely the mineral is present in several other samples as well.

Opal(?) occurs as irregular colorless isotropic grains with a low refractive index in several smear slides from the lower portion of the sediment section above and within basement. The shape suggests that the mineral was formed as an interstitial filling during initial lithification of wet sediments. Our identification of the mineral is, however, uncertain.

The mineralogy of the sediments recovered above the basement, as determined by x-ray diffraction, is similar to that of the hemipelagic sediments at Sites 482,483 , 
Table 10. Trace element composition of sediments, Hole 484A.

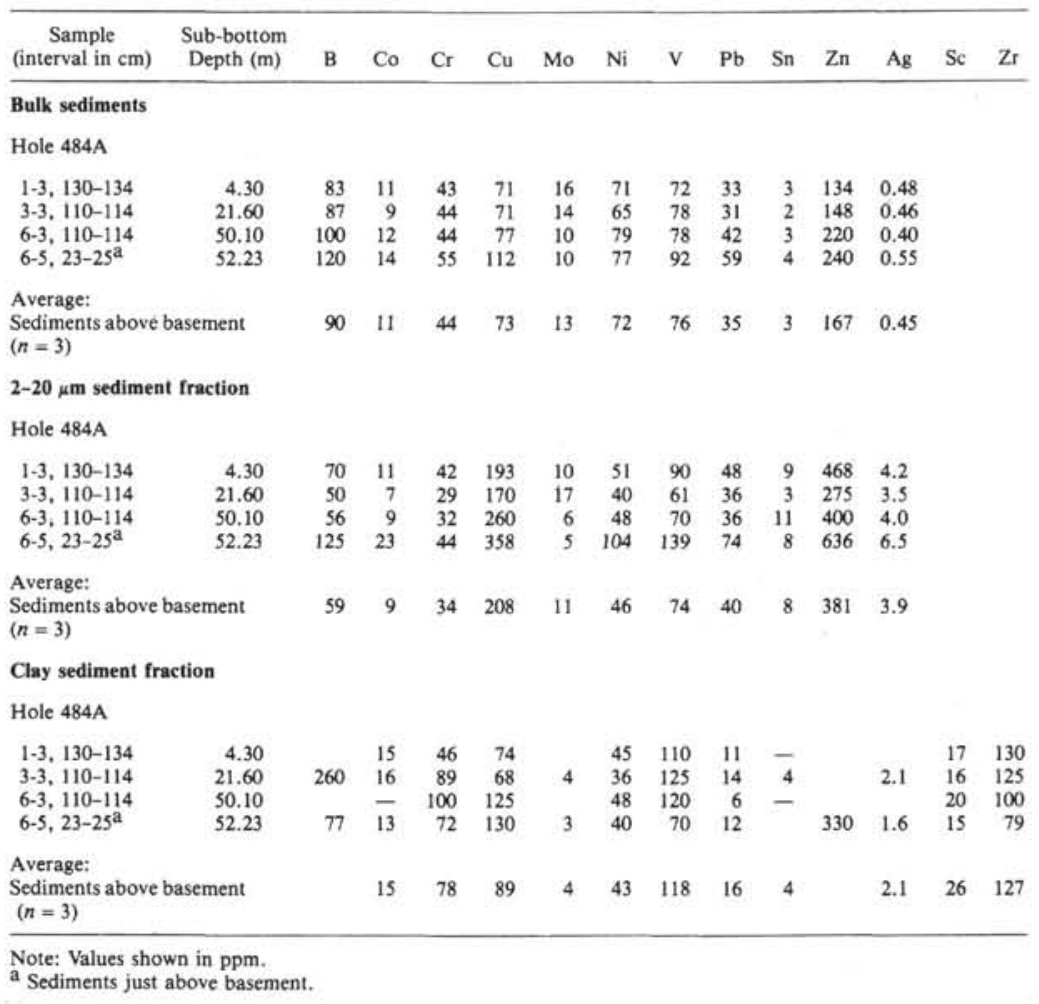

and 484 , but specific differences appear in some sediments intercalated within basalts.

In the clay fraction (Table 11), the clay mineral assemblage above basement is composed predominantly of smectite, which increases somewhat downhole up to $92 \%$ at 158 meters sub-bottom (near the basement). Mica and chlorite + kaolinite constitute the rest, showing irregular variations with depth. Quartz and feldspars occur as a minor admixture throughout. Clinoptilolite was detected in all samples above the basement. The clay mineral assemblage in the sediments within basement down to $231 \mathrm{~m}$ sub-bottom, as well as in the interval from 296 to 305 meters, is identical to that in the overlying sediments, but smectite content is commonly higher $(80-94 \%)$ and chlorite + kaolinite is extremely low (2-8\%). In three samples ( $236 \mathrm{~m}$ and $314 \mathrm{~m}$ sub-bottom), however, the clay minerals are quite different: pure smectite is absent, mica increases to $25 \%$, and mixed-layer mica-montmorillonite and chloritemontmorillonite predominate. Clinoptilolite was not found, but in the two lowermost samples we detected analcime.

The 2-20 $\mu \mathrm{m}$ fraction (Table 11) contains the same clay minerals as the clay fraction but smectite content is lower and mica content is markedly higher, particularly above 128 meters sub-bottom. Quartz, feldspars, and clinoptilolite are also more abundant. Mixed-layer minerals and analcime occur in the same samples in which they occur in the clay fraction. The coarse fraction (Table 11) is similar in composition to the $2-20 \mu \mathrm{m}$ fraction, but quartz, feldspars, clinoptilolite, and amorphous phases are even more abundant. As in the case of the clay fraction, clinoptilolite disappears in the sediments intercalated within the basement in both the $2-20 \mu \mathrm{m}$ and coarse fractions.

Mica in all samples is represented mainly by polytype $1 \mathrm{M}$, whereas $2 \mathrm{M}$ occurs as a minor admixture (Table 12). Smectites in the upper portion of the section are predominantly $\mathrm{Al}-\mathrm{Fe}$-montmorillonites, but $\mathrm{Fe}$-montmorillonite is also identified by $b$ repeat distances of 9.04-9.05 $\AA$ (Table 12) and by treatment with hot $10 \%$ $\mathrm{HCl}$ (Table 2). Below 79 meters sub-bottom, the basal reflection peak of the smectites broadens markedly on diffraction diagrams. In sediments just above and within basement, $\mathrm{Fe}$-montmorillonite is more abundant, particularly in the $2-20 \mu \mathrm{m}$ fraction. The smectites commonly show "cloudy" appearance, but elongated platy (ribbon-like) crystals also occur. Just above the basement the authigenic clay minerals display a fused or sintered(?) texture (Plate 2, Fig. 5).

Along with predominating smectites in these sediments intercalated within basalts, at sub-bottom depths of 236 and 313 meters, we identified mixed-layer minerals: mica-montmorillonite and chlorite-montmorillonite, together with analcime (Tables 11). The mixed-layer mica-montmorillonite (Sample 485A-28-1, 148-150 cm) has in the dry state a peak at $11.3 \AA$, which moves after treatment with glycol to $14.7 \AA$, and after heating at $550^{\circ} \mathrm{C}$ to $10 \AA$. This mineral is insoluble in $10 \% \mathrm{HCl}$ (Table 2). Heated samples show an additional peak at $10.6 \AA$, which corresponds to a mixed-layer chloritemontmorillonite. On transmission electron photomicrographs, the mixed-layer minerals occur as flat elongated crystals (Plate 1, Fig. 4). SEM photomicrographs show 
Table 11. Mineralogy of sediment fractions, Site 485 (in percent).

\begin{tabular}{|c|c|c|c|c|c|c|c|c|c|c|c|c|c|c|}
\hline $\begin{array}{c}\text { Sample } \\
\text { (interval in } \mathrm{cm} \text { ) }\end{array}$ & $\begin{array}{c}\text { Sub-bottom } \\
\text { Depth } \\
\text { (m) }\end{array}$ & Lithology & Age & Smectite & Mica & Chlorite & $\begin{array}{c}\text { Mixed-layer } \\
\text { Mica- } \\
\text { Montmorillonite }\end{array}$ & $\begin{array}{c}\text { Mixed-layer } \\
\text { Chlorite- } \\
\text { Montmorillonite }\end{array}$ & $\mathrm{z}$ & Quartz & Clinoptilolite & $\begin{array}{l}\text { Amorphous } \\
\text { Phase }\end{array}$ & Feldspar & Analcime \\
\hline \multicolumn{15}{|c|}{ Clay $(<2 \mu \mathrm{m})$ sediment fraction } \\
\hline \multicolumn{15}{|l|}{ Hole 485} \\
\hline $1-2,90-94$ & 2.40 & Unit IA & Upper Quaternary & 65 & 26 & 9 & & tr & 0.5 & it & c & tr & tr & \\
\hline $3-4,120-124$ & 18.20 & Silty clay & & 76 & 17 & 7 & & & 0.4 & it & c & Ir & tt & \\
\hline $4-2,120-124$ & 24.70 & & & 80 & 7 & 13 & & If & 0.4 & it & $c_{c}^{c}$ & tr & tt & \\
\hline $6-4,110-114$ & 46.60 & $\begin{array}{l}\text { Unit IB } \\
\text { Silty clay and nannofossil- } \\
\text { bearing silty clay }\end{array}$ & $\begin{array}{l}\text { Lower(?) } \\
\text { Quaternary }\end{array}$ & 75 & 16 & 9 & & tr & 0.5 & it & c & it & ut & \\
\hline Hole 485A & & & & & & & & & & & & & & \\
\hline $1-5,120-124$ & 52.10 & & & 73 & 14 & 13 & & ir & 0.4 & ts & c & tr & tr & \\
\hline $4-1,63-66$ & 79.63 & & & 75 & 15 & 10 & & ts & 0.5 & ts & c & ts & t & \\
\hline $5-3,111-115$ & 92.61 & Unit II & & 77 & 15 & 8 & & ir & 0.6 & ts & c & tr & ts & \\
\hline $6-3,11-15$ & 101.11 & Silty clay and turbidites & & 76 & 14 & 10 & & & 0.5 & tr & c & tr & tr & \\
\hline $8-2,114-118$ & 119.64 & & & 73 & 18 & 9 & & it & 0.5 & tr & c & tr & tr & \\
\hline $9-1,128-132$ & 127.78 & & & 78 & 15 & 7 & & & 0.5 & tr & c & ir & tr & \\
\hline $10-2,104-107$ & 138.54 & & & 88 & 9 & 3 & & it & 0.6 & tr & $c$ & tr & ts & \\
\hline $11-2,107-111$ & 148.07 & & & 84 & 13 & 3 & & & 0.6 & tr & c & tt & tr & \\
\hline $11-3,35-37^{a}$ & 158.35 & & & 92 & 6 & 2 & & & 0.5 & tr & c & ir & tt & \\
\hline $19-2,40-42^{b}$ & 189.90 & & & 66 & 25 & 9 & & & 0.6 & Ir & c & to & tr & \\
\hline $20-1,33-35^{b}$ & 192.83 & Sandy mud, muddy & & 81 & 13 & 6 & & & 0.6 & tr & & tr & tr & \\
\hline $20, C C^{b}$ & 197.02 & nannofossil chalk, and & & 80 & 12 & 8 & & & 0.7 & tr & & tr & tr & \\
\hline $22-2,24-26^{\mathrm{b}}$ & 203.24 & nannofossil-bearing & & 89 & 8 & 3 & & & 0.7 & if & & if & it & \\
\hline $22-4,33-36^{b}$ & 206.33 & silty claystone & & 90 & 7 & 3 & & & 0.6 & ts & & If & tr & \\
\hline $22-6,45-48^{\mathrm{b}}$ & 209.45 & & & 92 & 6 & 2 & & & 0.6 & ts & & is & tr & \\
\hline $26-1,48-50^{\mathrm{b}}$ & 226.48 & & & 90 & 7 & 3 & & & 0.7 & ts & & tr & tr & \\
\hline $27-1,46-48^{b}$ & 230.96 & & & 87 & 9 & 4 & & & 0.6 & ts & & ir & tr & \\
\hline $28-1,148-150^{b}$ & 236.48 & & & & 25 & 10 & 45 & 20 & & tr & & is & tr & \\
\hline $34-1,33-35^{b}$ & 277.33 & & & 47 & 35 & 18 & & & 0.2 & tr & & tr & ir & \\
\hline $36-1,61-65^{b}$ & 295.61 & & & 91 & 6 & 3 & & & 0.6 & tr & & Ir & tr & \\
\hline $36-2,58-61^{b}$ & 297.08 & & & 88 & 8 & 4 & & & 0.6 & it & & is & ts & \\
\hline $36-3,41-49^{b}$ & 298.41 & & & 94 & 4 & 2 & & & 0.6 & ts & & is & tr & \\
\hline $37-1,62-65^{b}$ & 304.62 & & & 94 & 4 & 2 & & & 0.5 & tt & & Ir & tr & \\
\hline $38-1,94-96^{b}$ & 313.94 & & & & 25 & 15 & & 60 & & c & & If & tr & c \\
\hline $38-1,98-100^{b}$ & 313.98 & & & tr & 25 & is & & 60 & & c & & ir & tr & c \\
\hline Intermediate $(2-20$ & am) sediment & raction & & & & & & & & & & & & \\
\hline Hole 485 & & & & & & & & & & & & & & \\
\hline $1-2,90-94$ & 2.40 & Unit IA & Upper Quaternary & 54 & 36 & 10 & & ti & 0.7 & d & d & ur & c & \\
\hline $3-4,120-124$ & 18.20 & Silty clay & & 55 & 35 & 10 & & ti & 0.6 & d & d & tr & c & \\
\hline $4-2,120-124$ & 24.70 & & & 57 & 34 & 9 & & tt & 0.5 & d & c & to & c & \\
\hline $6-4,110-114$ & 46.60 & Unit IB & Lower(?) & so & 37 & 13 & & tt & 0.6 & d & c & tr & c & \\
\hline & & $\begin{array}{l}\text { Silty clay and nannofossil. } \\
\text { bearing silty clay }\end{array}$ & Quaternary & & & & & & & & & & & \\
\hline Hole 485A & & & & & & & & & & & & & & \\
\hline $1-5,120-124$ & $\$ 2.10$ & & & 65 & 22 & 13 & & tr & 0.7 & d & c & tr & c & \\
\hline $3 \cdot 2,5-9$ & 71.05 & & & 73 & 17 & 10 & & tr & 0.6 & d & c & If & c & \\
\hline $4-1,63-66$ & 79.63 & & & 67 & 23 & 10 & & tr & 0.5 & e & e & tr & c & \\
\hline $5-3,111-115$ & 92.61 & Unit II & & 45 & 36 & 19 & & tr & 0.6 & d & c & ir & d & \\
\hline $6-3,11-15$ & 101.11 & Sitty clay and turbidites & & 48 & 38 & 14 & & is & 0.7 & d & e & tr & c & \\
\hline $8 \cdot 2,114-118$ & 119.64 & & & 58 & 28 & 14 & & it & 0.6 & d & c & if & c & \\
\hline $9-1,128-132$ & 127.78 & & & 64 & 24 & 12 & & is & 0.7 & d & c & it & c & \\
\hline $10-2,104-107$ & 138.54 & & & 72 & 20 & 8 & & tr & 0.6 & d & c & it & c & \\
\hline $11 \cdot 2,107-111$ & 148.07 & & & 81 & 15 & 4 & & tr & 0.7 & c & c & tr & c & \\
\hline $11-3,35-37^{\mathrm{a}}$ & 158.35 & & & 75 & 20 & 5 & & it & 0.7 & c & c & tr & c & \\
\hline $19 \cdot 2,40-42^{b}$ & 189.90 & Sandy mud, muddy & & 79 & 14 & 7 & & tr & 0.6 & c & tr & it & c & \\
\hline $20-1,33-35^{b}$ & 192.83 & & & 78 & 15 & 7 & & ir & 0.7 & c & & if & c & \\
\hline $20 . \mathrm{Cc}^{\mathrm{b}}$ & 197.02 & nannofossil-bearing & & 74 & 17 & 9 & & ts & 0.7 & d & & to & c & \\
\hline $22-2,24-26^{b}$ & 203.24 & silty claystone & & 78 & 18 & 4 & & if & 0.6 & c & & It & c & \\
\hline $22-4,33-36^{6}$ & 206.33 & & & 75 & 17 & 8 & & ti & 0.6 & c & & ti & c & \\
\hline $22-6,45-48^{b}$ & 209.45 & & & 70 & 19 & 11 & & it & 0.6 & d & & ir & c & \\
\hline $26-1,48-50^{b}$ & 226.48 & & & 83 & 11 & 6 & & it & 0.6 & c & & ts & c & \\
\hline $27 \cdot 1,46-48^{b}$ & 230.96 & & & 80 & 12 & 8 & & If & 0.6 & c & & it & c & \\
\hline $28-1,148-150^{b}$ & 236.48 & & & & 20 & 10 & 30 & 20 & & d & & tr & c & \\
\hline $34-1,33-35 b$ & 277.33 & & & 44 & 40 & 16 & & tf & 0.5 & d & & tr & c & \\
\hline $36-1,61-65^{b}$ & 295.61 & & & 82 & 13 & 5 & & if & 0.4 & c & & tr & c & \\
\hline $36-2,58-61^{b}$ & 297.08 & & & 77 & 18 & 5 & & it & 0.7 & c & & $\pi$ & c & \\
\hline $36-3,41-49^{b}$ & 298.41 & & & 78 & & 6 & & to & 0.6 & d & & tr & c & \\
\hline $37-1,62-65 b$ & 304.62 & & & 81 & 12 & $?$ & & ts & 0.5 & c & & if & c & \\
\hline $38-1,94-96^{b}$ & 313.94 & & & & 25 & 15 & & 60 & & d & & ir & c & \\
\hline $38-1,98-100^{b}$ & 313.98 & & & & 28 & 17 & & 55 & & d & & tr & c & \\
\hline Coarse $(>20 \mu \mathrm{m})$ & diment fractic & & & & & & & & & & & & & \\
\hline Hole 485 & & & & & & & & & & & & & & \\
\hline $1-2,90-94$ & 2.40 & Unit IA & Upper Quaternary & 62 & 30 & 8 & & "t & & & & & & \\
\hline & & Silty clay & & & & & & & 0.6 & d & c & d & d & \\
\hline Hole 485 A & & & & & & & & & & & & & & \\
\hline $6-3,11-15$ & 101.11 & Unit II & Lower(?) & 65 & 26 & 9 & & & 0.7 & d & d & d & & \\
\hline $11-2,107-111$ & 148.07 & Silty clay and turbidites & Quaternary & 77 & 16 & $?$ & & & 0.6 & d & d & d & $\mathrm{d}$ & \\
\hline $11-3,35-37^{\mathrm{a}}$ & 158.35 & & & 73 & 21 & 6 & & & 0.6 & d & c & d & d & \\
\hline $22-6,45-48^{\mathrm{b}}$ & 209.45 & Sandy mud, muddy & & 81 & 12 & 7 & & tr & 0.6 & $c$ & & c & tr & \\
\hline $26-1,48-50^{b}$ & 226.48 & nannofossil chalk, and & & 79 & 14 & 7 & & tr & 0.6 & c & & c & c & \\
\hline $28-1,148-150^{b}$ & 236.48 & nannofossil-bearing & & & 20 & 10 & 50 & 20 & & c & & c & c & \\
\hline $36-3,41-49^{6}$ & 298.41 & silty claystone & & 83 & 10 & 7 & & & 0.5 & $d$ & & c & c & ? \\
\hline $38-1,98-100^{b}$ & 313.98 & & & & 20 & 25 & & 55 & & d & & c & $c$ & c \\
\hline
\end{tabular}

a Sediments just above basement.

b Sediments interlayered within basement.

d Abundant.

e Arace. 
Table 12 . The $b$ repeat distances of clay minerals and mica polytypes in sediments, Site 485 .

\begin{tabular}{lccl}
\hline $\begin{array}{c}\text { Sample } \\
\text { (interval in cm) }\end{array}$ & $\begin{array}{c}\text { Sub-bottom } \\
\text { Depth } \\
(\mathrm{m})\end{array}$ & $\begin{array}{c}(\mathrm{b}) \\
(\mathrm{A})\end{array}$ & Mica Polytype \\
\hline Hole 485 & & & \\
& & & \\
$1-2,90-94$ & 2.40 & 9.02 & \\
$3-4,120-124$ & 18.20 & 9.05 & \\
Hole 485A & & & \\
& & & \\
$1-5,120-124$ & 52.10 & 9.02 & $1 \mathrm{M} \gg 2 \mathrm{M}_{1}$ \\
$6-3,11-15$ & 101.11 & $9.04 \geq 9.26$ & $1 \mathrm{M} \gg 2 \mathrm{M}_{1}$ \\
$9-1,128-138$ & 127.78 & $9.02 \geq 9.28$ & $1 \mathrm{M} \gg 2 \mathrm{M}_{1}$ \\
$11-3,35-37$ & 158.35 & $9.04 \geq 9.20$ & $1 \mathrm{M}$ \\
$19-2,40-42$ & 189.90 & $9.04 \geq 9.25$ & \\
$26-1,48-50$ & 226.48 & $9.05>9.28$ & $1 \mathrm{M} \gg 2 \mathrm{M}_{1}$ \\
$34-1,33-35$ & 277.33 & $9.01 \geq 9.23$ & \\
$36-2,58-61$ & 297.08 & $9.01 \geq 9.23$ & $1 \mathrm{M} \gg 2 \mathrm{M}_{1}$ \\
$38-1,98-100$ & 313.98 & $9.00<9.25$ & $1 \mathrm{M}>2 \mathrm{M}_{1}$ \\
\hline
\end{tabular}

the authigenic appearance of the clay minerals (Plate 2, Fig. 6).

Mixed-layer chlorite-montmorillonite in samples from Section 484A-38-1 in the dry state has a high, narrow, symmetrical peak at $13.83 \AA$ and a weak low-angle reflection. Other peaks for the mineral are superimposed on chlorite peaks at $7 \AA, 4.7 \AA$, and $3.5 \AA$. After saturation with glycol, the $13.83 \AA$ peak moves to $15.2-$ $15.4 \AA$, the $7-\AA$ peak becomes asymmetric, and the low-angle peak becomes sharper. After heating at $550^{\circ} \mathrm{C}$, the 13.83 peak moves to $13.4 \AA$. The mineral is soluble in hot $10 \% \mathrm{HCl}$ (Table 2) and is trioctahedral in structure with $b=9.25 \AA$ (Table 12). The crystal structure of the mineral is similar to that of corrensite. In transmission electron photomicrographs the mineral occurs as elongated plates or needle-like crystals (Plate 1, Figs. 5 and 6). Morphology of the authigenic minerals in samples from Section 38-1 is shown in Plate 3, Figures $1-6$. Since the sediments intercalated within basalts contain authigenic chlorite and mica phases, as well as analcime, it is likely that they have undergone hydrothermal alteration.

The coarse fraction ( $>20 \mu \mathrm{m}$ ) mineralogy was studied by the immersion method in 13 samples from Site 485 (Table 3), 7 of which are from layers in the basement. The heavy fraction content ranges from traces to 1.9 volume percent. It is composed of 44 to $100 \%$ pyrite and up to $16 \%$ unidentified black opaque minerals; the rest of the heavy minerals are transparent, including up to $13 \%$ authigenic barite. Barite occurs only in sediments intercalated within basement. The terrigenous mineral assemblage is similar to that previously described at other sites, but the percentage of transparent minerals in the heavy fraction is higher as a result of lower pyrite content in most samples. The epidote group predominates; hornblende, zircon, and apatite are common; and garnet, clinopyroxene, rutile, anatase, and sphene occur sporadically as rare grains.

The light fraction is composed of quartz, feldspars (mainly sodium plagioclase and potassium feldspar, but with some labradorite also present), and aggregate particles, the latter including clay pellets, rock fragments, and various minerals altered to chlorite or smectite. Zeolite was detected only in the uppermost sample. Gypsum occurs in several samples both above and below the sediment/basement contact.

\section{Geochemistry}

Bulk chemical composition was studied in both common hemipelagic mud far above basement and in sediments immediately overlying or within the basement (Tables 13, 14). The composition appeared to be rather monotonous throughout and similar to that at Sites 382 and 384. Silica content and $\mathrm{SiO}_{2}$ to $\mathrm{Al}_{2} \mathrm{O}_{3}$ ratios are close to those of average hemipelagic clay or of average shale, both in bulk samples and in clay fractions. The $2-20 \mu \mathrm{m}$ fraction is somewhat enriched in silica and the $\mathrm{SiO}_{2}$ to $\mathrm{Al}_{2} \mathrm{O}_{3}$ ratio ranges from 3.7 to 4.8 . The sediments with unusual clay mineralogy from Core 38 are somewhat enriched in silica (the $\mathrm{SiO}_{2}$ to $\mathrm{Al}_{2} \mathrm{O}_{3}$ ratio in bulk samples is 3.9).

The titanium content is low, and the $\mathrm{Al}$ to $\mathrm{Ti}$ ratio ranges both in bulk samples and in the less than $2 \mu \mathrm{m}$ fraction within the limits of 19 to 27 ; in several samples it is somewhat higher than that of average clay as a result of the extremely low $\mathrm{Ti}$ content. The ratio decreases in the $2-20 \mu \mathrm{m}$ fraction, as Ti content increases and $\mathrm{Al}$ decreases.

The total iron content ranges from 2.8 to 4.2 weight percent in bulk samples, but is commonly higher in the 2-20 $\mu \mathrm{m}$ fraction, ranging up to $6.8 \%$ in a sample just above basalt (Sample 485A-11-3, 35-37 cm), where we found abundant ankerite crystals, and up to $5.3 \%$ and $4.8 \%$, respectively, in two samples from sediments interlayered within the basement. The clay fraction does not show any noticeable increase in iron, as compared with bulk samples. $\mathrm{Fe}_{2} \mathrm{O}_{3}$ prevails over $\mathrm{FeO}$ both in bulk samples and in each of the size fractions examined, except for the lowermost sample, Sample 485A-38-1, 98$100 \mathrm{~cm}$, where the iron content is low and is represented mostly by $\mathrm{FeO}^{2}$. This sample is of unusual clay mineralogy and contains analcime.

We have not found regular downhole changes in any other constituents of the sediments. $\mathrm{MgO}$ and $\mathrm{CaO}$ variations are rather irregular, although $\mathrm{CaO}$ increases sharply (up to 4-6\%) in several bulk samples enriched in biogenic $\mathrm{CaCO}_{3}$. The highest value of total alkalinity (as expressed by the ratio of $\mathrm{K}_{2} \mathrm{O}+\mathrm{Na}_{2} \mathrm{O}$ to $\mathrm{Al}_{2} \mathrm{O}_{3}$ ) was found in a previously mentioned sample, $485 \mathrm{~A}-38-1,98-$ $100 \mathrm{~cm}$, in which the sodium content is also the highest observed. In other samples the total alkalinity values are uniform, the ratio being lowest in the clay fraction as a result of the decrease in sodium and increase in aluminum. The potassium to sodium ratio is more variable, particularly in the clay fraction, where it ranges from 0.8 (in a sample just above basement) up to 6.5 (in sediments with mixed-layer chlorite-montmorillonite), main-

\footnotetext{
${ }^{2} \mathrm{Fe}$ in pyrite is included in $\mathrm{Fe}_{2} \mathrm{O}_{3}$, since it is insoluble in reagents used for $\mathrm{FeO}$ deter-
} 
Table 13. Chemical composition of representative sediments, Holes 485 and $485 \mathrm{~A}$.

\begin{tabular}{|c|c|c|c|c|c|c|c|c|c|c|c|c|c|c|c|c|}
\hline \multirow[b]{3}{*}{ Component } & \multicolumn{16}{|c|}{$\begin{array}{c}\text { Sample } \\
\text { (interval in } \mathrm{cm} \text { ) }\end{array}$} \\
\hline & \multicolumn{3}{|c|}{$485-1-2,90-94 \mathrm{~cm}$} & \multicolumn{3}{|c|}{$485-6-4,110-114 \mathrm{~cm}$} & \multicolumn{3}{|c|}{$485 \mathrm{~A}-6-3,11-15 \mathrm{~cm}$} & \multicolumn{3}{|c|}{$485 \mathrm{~A}-10-2-104,107 \mathrm{~cm}$} & \multicolumn{2}{|c|}{$485 \mathrm{~A}-11-3,35-37 \mathrm{~cm}^{\mathrm{a}}$} & \multicolumn{2}{|c|}{$485 \mathrm{~A}-19-2,40-42 \mathrm{~cm}^{\mathrm{b}}$} \\
\hline & Bulk & $2-20 \mu \mathrm{m}$ & $<2 \mu \mathrm{m}$ & Bulk & $2-20 \mu \mathrm{m}$ & $<2 \mu \mathrm{m}$ & Bulk & $2-20 \mu \mathrm{m}$ & $<2 \mu \mathrm{m}$ & Bulk & $2-20 \mu \mathrm{m}$ & $<2 \mu \mathrm{m}$ & $2-20 \mu \mathrm{m}$ & $<2 \mu \mathrm{m}$ & Bulk & $2-20 \mu \mathrm{m}$ \\
\hline & 52.58 & 63.96 & 53.64 & 54.38 & 65.02 & 53.38 & 57.36 & 62.08 & 54.30 & 55.78 & 62.60 & 54.02 & 56.06 & 53.50 & 57.62 & 56.98 \\
\hline $\mathrm{TiO}_{2}$ & 0.49 & 0.56 & 0.56 & 0.55 & 0.58 & 0.71 & 0.62 & 0.62 & 0.73 & 0.58 & 0.66 & 0.73 & 0.66 & 0.75 & 0.49 & 0.71 \\
\hline $\mathrm{Al}_{2} \mathrm{O}_{3}$ & 13.94 & 14.50 & 16.23 & 13.88 & 13.45 & 17.71 & 13.90 & 13.09 & 17.34 & 14.80 & 14.12 & 17.51 & 13.64 & 16.55 & 13.50 & 15.57 \\
\hline $\mathrm{Fe}_{2} \mathrm{O}_{3}$ & 4.30 & 3.29 & 4.46 & 2.49 & 3.43 & 2.66 & 2.54 & 2.96 & 3.83 & 3.14 & 3.42 & 3.25 & 7,00 & 6.07 & 3,81 & 6.23 \\
\hline $\mathrm{FeO}$ & 1.12 & 0.78 & 1.14 & 1.36 & 0.78 & 1.53 & 1.84 & 2.88 & 1.19 & 1.36 & 1.43 & 1.26 & 2.45 & 0.41 & 0.82 & 1.16 \\
\hline $\mathrm{MnO}$ & 0.11 & 0.07 & 0.06 & 0.07 & 0.08 & 0.07 & 0.06 & 0.08 & 0.06 & 0.06 & 0.07 & 0.05 & 0.13 & 0.05 & 0.06 & 0.09 \\
\hline $\mathrm{MgO}$ & 2.26 & 1.45 & 2.42 & 2.58 & 1.85 & 3.06 & 2.90 & 2.66 & 3.38 & 2.90 & 2.18 & 3.06 & 2.26 & 2.58 & 2.98 & 2.52 \\
\hline $\mathrm{CaO}$ & 3.02 & 1.90 & 0.45 & 4.48 & 1.79 & 0.56 & 3.58 & 1.79 & 1.23 & 2.69 & 1.57 & 1.23 & 2.46 & 1.34 & 6.16 & 2.24 \\
\hline $\mathrm{Na}_{2} \mathrm{O}$ & 3.20 & 2.33 & 0.94 & 2.72 & 2.24 & 0.62 & 2.60 & 2.23 & 0.67 & 2.12 & 2.60 & 0.5 & 1.80 & 3.18 & 2.60 & 1.36 \\
\hline $\mathrm{K}_{2} \mathrm{O}$ & 2.70 & 3.00 & 2.31 & 2.25 & 2.89 & 2.00 & 3.00 & 3.33 & 3.00 & 3.62 & 2.62 & 2.62 & 2.50 & 2.45 & 2.62 & 2.80 \\
\hline $\mathrm{P}_{2} \mathrm{O}_{5}$ & 0.08 & 0.04 & 0.18 & 0.19 & 0.19 & 0.13 & 0.21 & 0.20 & 0.14 & 0.13 & 0.19 & 0.13 & 0.16 & 0.04 & 0.33 & 0.07 \\
\hline $\mathrm{LOH}^{+}$ & 15.8 & 7.8 & 17.4 & 14.5 & 7.5 & 17.00 & 10.8 & 7.5 & 13.8 & 12.4 & 8.1 & 15.1 & 10.3 & 12.9 & 8.70 & 9.7 \\
\hline Total & 99.60 & 99.68 & 99.79 & 99.45 & 99.80 & 99.43 & 99.41 & 99.42 & 99.67 & 99.58 & 99.56 & 99.46 & 99.42 & 99.82 & 99.69 & 99.43 \\
\hline $\mathrm{K}_{2} \mathrm{O} / \mathrm{Na}_{2} \mathrm{O}$ & 0.84 & 1.29 & 2.46 & 0.83 & 1.29 & 3.22 & 1.15 & 1.49 & 4.48 & 1.71 & 1.00 & 5.24 & 1.39 & 0.77 & 1.00 & 2.06 \\
\hline $\mathrm{K}_{2} \mathrm{O}+\mathrm{Na}_{2} \mathrm{O} / \mathrm{Al}_{2} \mathrm{O}_{3}$ & 0.42 & 0.37 & 0.20 & 0.36 & 0.38 & 0.15 & 0.40 & 0.42 & 0.21 & 0.39 & 0.37 & 0.18 & 0.32 & 0.34 & 0.39 & 0.27 \\
\hline $\mathrm{Fe}_{2} \mathrm{O}_{3}+\mathrm{FeO}+\mathrm{MgO} / \mathrm{Al}_{2} \mathrm{O}_{3}$ & 0.55 & 0.38 & 0.49 & 0.46 & 0.45 & 0.41 & 0.52 & 0.65 & 0.48 & 0.50 & 0.50 & 0.43 & 0.86 & 0.55 & 0.56 & 0.64 \\
\hline $\mathrm{SiO}_{2} / \mathrm{Al}_{2} \mathrm{O}_{3}$ & 3.77 & 4.41 & 3.30 & 3.92 & 4.83 & 3.01 & 4.13 & 4.74 & 3.13 & 3.77 & 4.43 & 3.08 & 4.11 & 3.23 & 4.27 & 3.66 \\
\hline $\mathrm{Fe}$ & 3.88 & 2.91 & 4.01 & 2.80 & 3.01 & 3.05 & 3.21 & 4.32 & 3.61 & 3.26 & 3.50 & 3.25 & 6.81 & 4.57 & 3.31 & 5.26 \\
\hline $\mathrm{Al} / \mathrm{Ti}$ & 25.48 & 22.59 & 25.29 & 22.27 & 20.37 & 21.83 & 19.92 & 18.76 & 20.89 & 22.4 & 19.18 & 21.01 & 18.54 & 19.49 & 24.65 & 19.19 \\
\hline
\end{tabular}

Note: Values shown in weight percent.

a Sediments immediately overlying basement.

b Sediments intercalated within basalts.

Table 14. Average composition of sediments, Site 485.

\begin{tabular}{|c|c|c|c|c|c|c|c|c|c|}
\hline \multirow[b]{2}{*}{ Component } & \multicolumn{3}{|c|}{$\begin{array}{l}\text { Sediments above } \\
\text { Basement }\end{array}$} & \multicolumn{3}{|c|}{$\begin{array}{l}\text { Sediments Intercalated } \\
\text { within Basalts }\end{array}$} & \multicolumn{3}{|c|}{$\begin{array}{l}\text { Mixed-layer Chlorite- } \\
\text { Montmorillonite-bearing } \\
\text { Sediments Intercalated } \\
\text { within Basalts }\end{array}$} \\
\hline & $\begin{array}{c}\text { Bulk } \\
(n=4)\end{array}$ & $\begin{array}{l}2-20 \mu \mathrm{m} \\
(n=4)\end{array}$ & $\begin{array}{l}<2 \mu \mathrm{m} \\
(n=4)\end{array}$ & Bulk & $2-20 \mu \mathrm{m}$ & $<2 \mu \mathrm{m}$ & Bulk & $2-20 \mu \mathrm{m}$ & $<2 \mu \mathrm{m}$ \\
\hline $\mathrm{SiO}_{2}$ & 55.02 & 63.42 & 53.84 & 55.61 & 60.40 & 57.30 & 60.42 & 64.95 & 60.54 \\
\hline $\mathrm{TiO}_{2}$ & 0.56 & 0.60 & 0.68 & 0.59 & 0.66 & 0.62 & 0.73 & 0.56 & 0.73 \\
\hline $\mathrm{Al}_{2} \mathrm{O}_{3}$ & 14.13 & 13.79 & 17.20 & 15.20 & 15.30 & 16.28 & 15.53 & 16.27 & 17.18 \\
\hline $\mathrm{Fe}_{2} \mathrm{O}_{3}$ & 3.12 & 3.28 & 3.55 & 3.47 & 5.10 & 3.67 & 1.93 & 0.87 & 2.65 \\
\hline $\mathrm{FeO}$ & 1.42 & 1.47 & 1.28 & 1.44 & 1.10 & 1.23 & 2.07 & 1.47 & 1.74 \\
\hline $\mathrm{MnO}$ & 0.08 & 0.08 & 0.06 & 0.06 & 0.08 & 0.04 & 0.04 & 0.03 & 0.11 \\
\hline $\mathrm{MgO}$ & 2.66 & 2.04 & 2.98 & 2.68 & 2.19 & 2.85 & 2.82 & 1.83 & 3.71 \\
\hline $\mathrm{CaO}$ & 3.44 & 1.76 & 0.87 & 4,14 & 1.79 & 0.82 & 1.34 & 0.78 & 0.45 \\
\hline $\mathrm{Na}_{2} \rho$ & 2.66 & 2.35 & 0.68 & 2.18 & 1.36 & 1.20 & 4.40 & 3.92 & 0.58 \\
\hline $\mathrm{K}_{2} \mathrm{O}$ & 2.89 & 2.96 & 2.48 & 3,04 & 3.13 & 3.28 & 3.44 & 3.85 & 3.75 \\
\hline $\mathrm{P}_{2} \mathrm{O}_{5}$ & 0.15 & 0.16 & 0.14 & 0.20 & 0.09 & 0.16 & 0.16 & 0.10 & 0.28 \\
\hline $\mathrm{LOI}^{+}$ & 13.38 & 7.72 & 15.82 & 11.02 & 8.30 & 12.00 & 6.90 & 4.80 & 7.80 \\
\hline $\mathrm{K}_{2} \mathrm{O} / \mathrm{Na}_{2} \mathrm{O}$ & 1.09 & 1.26 & 3.65 & 1.38 & 2.30 & 2.73 & 0.78 & 0.98 & 6.46 \\
\hline $\mathrm{K}_{2} \mathrm{O}+\mathrm{Na}_{2} \mathrm{O} / \mathrm{Al}_{2} \mathrm{O}_{3}$ & 0.39 & 0.38 & 0.18 & 0.37 & 0.29 & 0.28 & 0.50 & 0.48 & 0.25 \\
\hline $\mathrm{Fe}_{2} \mathrm{O}_{3}+\mathrm{FeO}+\mathrm{MgO} / \mathrm{Al}_{2} \mathrm{O}_{3}$ & 0.51 & 0.49 & 0.45 & 0.50 & 0.55 & 0.48 & 0.44 & 0.26 & 0.47 \\
\hline
\end{tabular}

ly as a result of changing sodium content. Phosphorus is low throughout the section studied.

Trace elements were analyzed in 18 samples from Site 485 , including 9 samples from sediments intercalated within basalts and 1 from just above basement. Along with bulk samples, we analyzed the clay fraction and the 2-20 $\mu$ m fraction (Table 15).

The bulk samples show rather insignificant variations in concentrations of trace elements without any increasing (or decreasing) trend in sediments intercalated within basalts. The concentrations and average values are close to those determined at Sites 482 and 484 , but $\mathrm{Cu}$, $\mathrm{Ni}, \mathrm{V}$, and $\mathrm{Zn}$ contents are lower than those at Site 483. Such trace elements as $\mathrm{Zn}, \mathrm{Cu}, \mathrm{Ag}$, and $\mathrm{Sn}$ tend to be concentrated in the 2-20 $\mu \mathrm{m}$ fraction (Table 15). The high concentrations of $\mathrm{Zn}$ (up to $995 \mathrm{ppm}$ ), $\mathrm{Cu}$ (up to $570 \mathrm{ppm}$ ), $\mathrm{Sn}$ (up to $32 \mathrm{ppm}$ ), and $\mathrm{Ag}$ (up to $6.5 \mathrm{ppm}$ ) in this fraction occur both above and within basement; however, average values apparently show an increasing trend with depth in the latter. The clay fraction (Table 15 ) is relatively enriched in $\mathrm{Cr}$ and $\mathrm{V}$, whereas $\mathrm{Zn}, \mathrm{Cu}$, $\mathrm{Sn}$, and $\mathrm{Ag}$ are commonly less abundant in this fraction than in the $2-20 \mu \mathrm{m}$ fraction.

\section{MINERALOGY AND CHEMICAL COMPOSITION OF SEDIMENTS FROM THE MOUTH OF THE GULF OF CALIFORNIA}

The Quaternary and upper Pliocene hemipelagic sediments drilled during Leg 65 are composed mainly of terrigenous material-both clay and clastic minerals, derived from nearby mainland Mexico, with minor admixtures of biogenic and authigenic constituents. Composition of the terrigenous material is rather monotonous at all sites throughout the sediment sections drilled. Smectites, represented by aluminous montmorillonite with a dioctahedral structure in which the aluminum is partially replaced by ferric iron, predominate over mica in clay mineral assemblages, while chlorite + kaolinite occur as a minor admixture. Ferric montmorillonite belonging to the $\mathrm{Fe}-\mathrm{Al}$-smectite group of Drits and Kossovskaya (1980) is also detected in the sediments, but it is, at least partially, of authigenic origin. The terrigenous smectites show an irregular "cloudy" appearance on electron photomicrographs, whereas the authigenic smectites are represented by flat, elongate crystals or by "honeycomb" textures. 
Table 15. Trace element composition of sediments, Site 485.

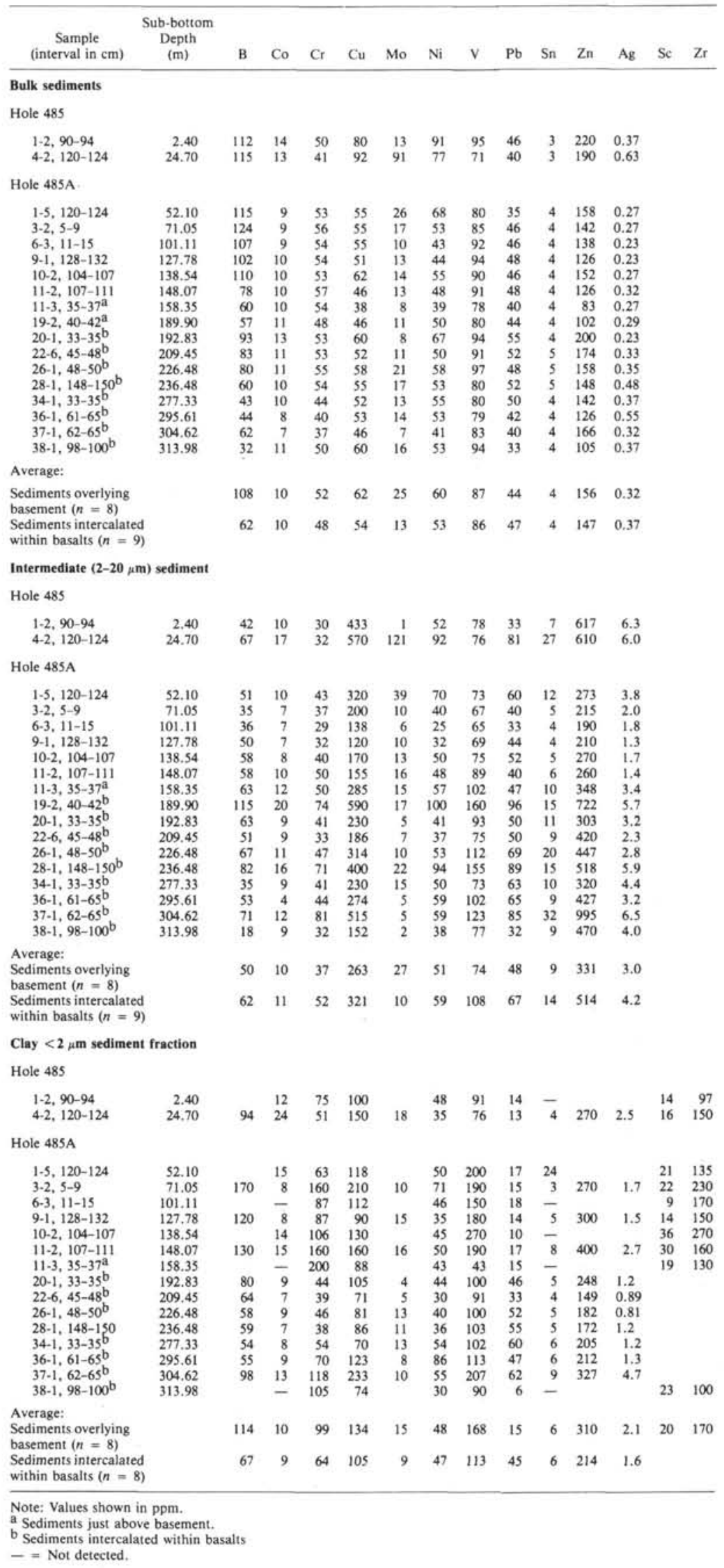


The terrigenous clastic material is composed mainly of quartz and feldspars, the latter represented by sodium plagioclase and potassium feldspar with minor amounts of labradorite. In coarse fractions, quartz and feldspars occur in approximately equal amounts, but commonly the feldspars somewhat predominate, indicating an immature terrigenous mineral assemblage. The transparent heavy mineral fraction is represented by an epidote-hornblende-zircon-apatite assemblage in which epidote strongly predominates. This assemblage is typical of the sediments associated with the circumPacific Mesozoic-Cenozoic orogenic belt.

Biogenic constituents occur in minor amounts. Biogenic opal (diatoms, radiolarians, and sponge spicules) is common in the upper portions of sediment sections at all sites. It becomes rare below 50 meters and disappears below 100 meters at Site 482 (upper Quaternary); becomes rare below 70 meters and disappears below 90 meters at Site 483 (lower Quaternary); becomes rare below 50 meters at Site 484 (upper Quaternary); becomes rare below 50 meters and virtually disappears below 90 meters at Site 485 (lower Quaternary). Just above the complete disappearance level, we observed partly dissolved forms. The dissolution features together with the different stratigraphic positions of the disappearance level provide evidence of diagenetic dissolution of the biogenic opal, likely stimulated by heating of the sediment column from below. The distribution of biogenic carbonates, on the other hand, is rather irregular, likely reflecting differences in primary sedimentation.

Along with terrigenous and biogenic minerals we identified several authigenic constituents. Some of the authigenic minerals (pyrite, carbonates) show distribution patterns that are independent of sub-bottom depth or proximity to basalt, whereas others, such as barite, mixed-layer chlorite-montmorillonite and illite-montmorillonite ( \pm mica), swelling chlorite, ferric montmorillonite, analcime, and gypsum, occur mainly (or solely) in sediments close to the sediment/basement contact or intercalated within basement, thus likely being related either to hydrothermal activity or to heating by hot basalt. We found two layers within basement at Site 485 in which clay minerals are represented mainly by authigenic mixed-layer phases with analcime, and a layer at Site 482 which is entirely composed of authigenic (hydrothermal) illite-montmorillonite $(+$ mica) and swelling chlorite. One sample from Hole 482 , about 7 meters above the basalt contained dolomite-ankerite. Clinoptilolite is absent from zones of possible hydrothermal influence, occurring only in the upper parts of sediment sections.

The bulk chemical composition of sediments from the mouth of the Gulf is similar to that of common hemipelagic terrigenous clay and silty clay found elsewhere (e.g., Goldberg and Arrhenius, 1958; Landergreen, 1964; Mikhailov, 1980; Kurnosov et al., in press; Murdmaa et al., 1979, 1980). As compared with the Miocene hemipelagic clay in the western North Atlantic (Murdmaa et al., 1979), which is also mainly smectitic, the sediments considered here contain less aluminum, titanium, and iron, but more alkali metals and calcium, the latter associated in part with biogenic carbonate. They differ from Japan trench hemipelagic sediments (Murdmaa et al., 1980) in having a lower silica content as a result of the scarcity of siliceous microfossils, but the interrelations between other constituents are similar.

We compared the bulk chemistry of the sediments from the mouth of the Gulf of California with that of continental arkoses and graywackes (Middleton, 1960; Baily et al., 1964; Ronov et al., 1965; Schwab, 1971; Crook, 1974; Shutov, 1975) and found that percentages of most constituents, as well as the values of the $\mathrm{K}_{2} \mathrm{O}$ / $\mathrm{Na}_{2} \mathrm{O}, \mathrm{K}_{2} \mathrm{O}+\mathrm{Na}_{2} \mathrm{O} / \mathrm{Al}_{2} \mathrm{O}_{3}$, and $\mathrm{Fe}_{2} \mathrm{O}_{3}+\mathrm{FeO}+\mathrm{MgO} /$ $\mathrm{Al}_{2} \mathrm{O}_{3}$ ratios, resemble those obtained in argillaceous members of the upper Cretaceous to Miocene flysch deposits in the eastern Kamchatka (Markevich, Chudaev, 1979).

The composition of the various size fractions examined often differs markedly from that of bulk samples, showing different contributions of clay, clastic minerals, and biogenic constituents to the total sediment chemistry. The $2-20 \mu \mathrm{m}$ fraction is generally enriched in silica $\left(\mathrm{SiO}_{2} / \mathrm{Al}_{2} \mathrm{O}_{3}>+4\right)$ compared with bulk samples and with the clay fraction due to the presence of clastic quartz and partially to biogenic opal. Titanium and aluminum, on the contrary, are higher in the clay fraction, as these elements are associated with clay minerals.

The behavior of iron is more complicated, because it occurs in many minerals of different origin, such as smectites, authigenic pyrite, ankerite, free hydrated oxides, and a wide variety of clastic minerals. As a result, total iron is sometimes greatest in the $2-20 \mu \mathrm{m}$ fraction and sometimes in the clay fraction. A significant increase in iron (more than 5\%) was found in the 2-20 $\mu \mathrm{m}$ fraction from Hole 485A, Cores 11 and 19, both just above basalts. Sample 485A-11-3, 35-37 cm contains in a smear slide abundant ankerite(?) crystals, and Sample $485 \mathrm{~A}-19-2,40-42 \mathrm{~cm}$ is enriched in pyrite. The samples with unusual clay mineralogy (mixed-layer clay minerals or illite-montmorillonite plus mica) at Sites 482 and 485 do not show a regular change in total iron with depth in any fraction, but $\mathrm{FeO}$ is more abundant in these samples than is $\mathrm{Fe}_{2} \mathrm{O}_{3}$. However, oxidation states (i.e., $\mathrm{Fe}_{2} \mathrm{O}_{3} /$ $\mathrm{FeO}$ ) inferred from the analyses presented here are unreliable, because the iron in pyrite is included in the values shown for $\mathrm{Fe}_{2} \mathrm{O}_{3}$. So the increase in total iron and $\mathrm{Fe}_{2} \mathrm{O}_{3}$ in several samples of the $2-20 \mu \mathrm{m}$ fraction is likely on account of pyrite, as the pyrite spherules and crystals fall mainly in this size range.

Manganese content is low throughout the set of samples analyzed, indicating early diagenetic removal of the element under reducing conditions.

Magnesium is relatively concentrated in the clay fraction, being associated with clay minerals. Calcium, on the contrary, is higher in coarse fractions, following the distribution of biogenic calcite.

Total alkalinity $\left(\mathrm{K}_{2} \mathrm{O}+\mathrm{Na}_{2} \mathrm{O} / \mathrm{Al}_{2} \mathrm{O}_{3}\right)$ appeared to be higher in the $2-20 \mu \mathrm{m}$ fraction than in the clay fraction mainly because of higher sodium and lower aluminum percentages. The potassium to sodium ratio markedly increases in the clay fraction, as sodium decreases. This is consistent with sodium being associated mainly with 
plagioclase and clinoptilolite and potassium being incorporated within clay minerals, in both smectites $(\mathrm{Fe}-$ montmorillonite) and mica.

Trace elements show the concentration range typical for reduced hemipelagic sediments. Zinc in bulk samples strongly prevails over other elements (more than $100 \mathrm{ppm}$ and up to $440 \mathrm{ppm}$ ). The next most abundant elements are $\mathrm{V}, \mathrm{B}, \mathrm{Ni}$, and $\mathrm{Cu}$ (characteristic values 50-100 ppm). The third group comprises $\mathrm{Cr}$ and $\mathrm{Pb}$ (commonly $30-60 \mathrm{ppm}$ ). Molybdenum concentration is generally lower, but shows wide variations (7-91 ppm, with common values ranging within $10-30 \mathrm{ppm})$. Cobalt content $(7-18 \mathrm{ppm})$ is commonly lower than that of molybdenum. Tin concentration $(2-4 \mathrm{ppm})$ is close to the level of detection, and silver $(0.19-0.55 \mathrm{ppm})$ is only marginally detectable.

Such trace elements as $\mathrm{Zn}, \mathrm{Cu}, \mathrm{Sn}$, and $\mathrm{Ag}$, and to a smaller extent, $\mathrm{Co}$ and $\mathrm{Ni}$ tend to have higher concentrations in the $2-20 \mu \mathrm{m}$ fraction as compared with bulk samples. This probably reflects the presence of authigenic pyrite in the $2-20 \mu \mathrm{m}$ fraction. Chromium, vanadium, and boron all tend to concentrate in the clay fraction.

Comparing the trace elements at different sites we found that sediments are richest in $\mathrm{Zn}, \mathrm{Cu}, \mathrm{Ni}, \mathrm{Co}$, and $\mathrm{V}$ in both bulk samples and individual size fractions at Site 483. At other sites similar high values occur in the $2-20 \mu \mathrm{m}$ fraction of sediments intercalated within basalts or just above basement. The spectral analysis data, however, should be used with care because some of the concentrations observed in size fractions contradict those in bulk samples (particularly in the case of silver).

\section{HYDROTHERMAL ALTERATION OF SEDIMENTS}

One of the objectives of this study was to determine the effects of hydrothermal activity and high heat flow on the sediment composition in the vicinity of a young active rift system. Throughout this study, the sediments immediately overlying basement and those intercalated within basement have been distinguished from the sediment section far above basement in order to discern such effects. However, in most cases we failed to find regular changes which might be attributed to alteration under high temperature or extensive infiltration of juvenile hydrothermal solutions. Nevertheless the sediments display some unusual features, which may be best explained as the result of weak thermal alteration.

As we noted above, the upper Quaternary sediments at all sites contain clinoptilolite, which disappears downhole with increasing temperature. Such young clinoptilolite-bearing sediments are uncommon themselves, but even more unusual is the disappearance of clinoptilolite at sub-bottom depths of about 110 to 160 meters near basement. Siliceous biogenic particles disappear somewhat higher in the section, probably as a result of dissolution under conditions of increased temperature.

The heating of sediments possibly stimulates formation of such authigenic minerals as barite, gypsum, and carbonates of the dolomite-ankerite group. The appearance of these minerals in thin sections (spherulitic and poikiloblastic textures, euhedral crystals with sediment inclusions) suggests that they formed in situ. Although these authigenic minerals occur throughout the section, we noted an increase in their frequency near and within basement, where temperatures must have been higher. Radiating spherulites of barite, for example, were found only in the lower part of the sediment section (beginning about $27 \mathrm{~m}$ above the basement) at Site 482 and in sediments intercalated within basement at Sites 482, 483, and 485 . Similarly, poikiloblastic carbonate (dolomite?) micronodules occur in two lowermost sediment samples at Site 485 (those composed of authigenic mixed-layer clay minerals and analcime), and dolomite-ankerite crystals are common near the sediment/basement contact and within the basement in Hole $482 \mathrm{C}$. As suggested by Hein et al. (1979) from studies of sediments in the Bering Sea, such carbonates may well be of hydrothermal origin.

We hesitate to include pyrite among the hydrothermal minerals, because unlike barite, gypsum, and ankerite, it is a common early diagenetic mineral in reduced hemipelagic sediments elsewhere. However, any additional iron of hydrothermal origin is likely to be bound up in pyrite, and some sediments rich in pyrite within the basement may have been affected by such activity near the ridge crest.

The high heat flow observed at the Leg 65 sites probably results in alteration of primary terrigenous clay minerals or leads to the formation of new ones. We noted authigenic crystallographic forms of ferric montmorillonite (ribbon-like crystals) (Kossovskaya, 1975) near the sediment/basalt contacts and detected authigenic (probably hydrothermal) mixed-layer clay minerals in several beds at the sediment/basalt contact or intercalated within basalts. The authigenic minerals predominate in the clay mineral assemblages in these beds or compose them entirely and consist of mixed-layer illite-montmorillonite (+mica) together with swelling chlorite at Site 482 and mixed-layer mica-montmorillonite together with chlorite-montmorillonite at Site 485. In Core 485A-38 the mixed-layer clay minerals are associated with analcime, likely of hydrothermal origin. The downhole increase in ferric montmorillonite may be attributed to a low-temperature hydrothermal process as well.

Changes in bulk chemistry of sediments near the sediment/basalt contact and within the basement are rather insignificant. We have not noted any regular increase in iron or manganese in these layers, except for a sample just above basement at Site 485 , where iron content in the $2-20 \mu \mathrm{m}$ fraction is $6.8 \%$. Thus, true metalliferous sediments are absent, in spite of high heat flow and the previously mentioned mineralogical evidence of hydrothermal activity.

However, the layers with unusual authigenic clay minerals differ somewhat chemically from common hemipelagic sediments. Those with illite-montmorillonite (+ mica) and swelling chlorite at Site 482 show an increase in $\mathrm{Al}_{2} \mathrm{O}_{3}, \mathrm{FeO}$, and $\mathrm{MgO}$ contents and in the $\mathrm{K}_{2} \mathrm{O}$ to $\mathrm{Na}_{2} \mathrm{O}$ ratio in the clay fraction. Those with hydrothermal mixed-layer mica-montmorillonite and chlorite- 
montmorillonite from Core 485A-38 are somewhat enriched in silica, but poor in iron (especially in $\mathrm{Fe}_{2} \mathrm{O}_{3}$ ). At the same time, the clay fraction in this material displays the highest potassium to sodium ratio, while the coarser fractions are relatively enriched in sodium.

The variations in trace elements seem to be independent of their distance from basalts, and their concentration in sediments just above or within basement does not increase regularly with depth as might be expected if they were related to hydrothermal activity. The average values show an increase in $\mathrm{Zn}, \mathrm{Cu}, \mathrm{Pb}$, and $\mathrm{Ag}$ in the $2-20 \mu \mathrm{m}$ fraction from sediments intercalated within basement at Sites 482 and 485 , but none in the bulk samples. The maximum concentrations of most trace elements occur together both above and within basement. The samples with unusual, probably hydrothermal, mineralogy are rather poor in trace elements.

It should be emphasized that none of the trace elements studied occurs in concentrations markedly exceeding the limits characteristic for common hemipelagic sediments. Some relatively high values of zinc and copper occur among the bulk samples analyzed, particularly in the lower portions of sediment sections, but they show little relation to the basalts. These concentrations may be related to hydrothermal activity, but more likely are associated with authigenic iron sulfides derived from interstitial waters. The high concentrations of both trace elements and pyrite in the $2-20 \mu \mathrm{m}$ fraction confirms the assumption.

In any case, we have not found high concentrations of the trace elements like those in metalliferous sediments from the Red Sea or the East Pacific Rise. Any hydrothermal activity in the vicinity of the sites was thus too weak or distant to overcome either dilution in the voluminous terrigenous sediments deposited in the area or migration of the elements under the strongly reducing conditions which prevailed during early diagenesis.

\section{CONCLUSIONS}

Adjacent to an active spreading center in the Gulf of California, terrigenous hemipelagic sediments are rapidly accumulating, composed of clay minerals (with $\mathrm{Al}$ - or $\mathrm{Al}-\mathrm{Fe}$-smectite as the dominant constituent), quartz, and feldspars. The minor components of the sediments are terrigenous heavy minerals, biogenic silica, and calcium carbonate and authigenic clinoptilolite, pyrite, ferric montmorillonite, mixed-layer clay minerals, and carbonates of dolomite-ankerite group. Barite and gypsum occur in trace amounts.

Notwithstanding the high thermal gradients and heat flow in the region, we found only minor geochemical or mineralogic evidence of hydrothermal alteration of the sediments even in beds just above basement or in those intercalated within basalts. This is consistent with the fact that the basalts, for the most part, are only slightly altered. The basalts are generally massive, well crystallized, relatively unfractured, and only slightly vesicular, which suggests that the magmas were relatively dry and contained only limited amounts of volatiles. Therefore, the volcanism commonly associated with rather weak hydrothermal activity and extensive infiltration of juve- nile hydrothermal solutions into the sediment column has not taken place.

The observed changes in mineral composition of the terrigenous sediments, such as authigenic clay mineral formation (ferric montmorillonite in flat, elongate crystals, mixed-layer chlorite-montmorillonite, mica-montmorillonite \pm mica, and swelling chlorite), precipitation of barite, gypsum, dolomite-ankerite, and analcime, as well as downhole dissolution of siliceous microfossils and the disappearance of clinoptilolite, are likely caused by heating of the water-saturated sediments, rather than by the infiltration of hydrothermal solutions into the sediments or the interaction of such solutions with bottom waters.

The previously mentioned authigenic minerals do not result in significant changes in total chemical composition of the terrigenous hemipelagic sediments studied. The mobile forms of iron are precipitated during early diagenetic breakdown of organic matter under reducing conditions as authigenic pyrite, and partially as ankerite, the latter being likely stimulated by increased temperature. We have not found any chemical evidence of metalliferous sediments either in major or in trace elements. The chemical properties of sediments above and within basement vary within limits characteristic of common terrigenous hemipelagic sediments. The very high sedimentation rates in the region may result in dilution of metals derived from the hydrothermal sources commonly associated with active spreading centers.

\section{ACKNOWLEDGMENTS}

The authors thank M. A. Mikhailov, N. V. Ryapolova, G. A. Yudina, Y. Kaminskaya, and R. L. Leonova for help in making the analyses and in preparing the manuscript. We acknowledge the help of Dr. N. S. Skornyakova and Prof. P. L. Bezrukov who reviewed the paper. We are indebted to the members of the scientific and technical staff of the Glomar Challenger on Leg 65 for sample collection.

\section{REFERENCES}

Bailey, E. H., Yrwin, W. P., and Jones, D. L., 1964. Franciscan and related rocks, and their significance in the geology of Western California. Bull. Calif. Div. Mines Geol., 183:3-171.

Biscaye, P. E., 1964. Mineralogy and sedimentation of the deep-sea sediment fine fraction in the Atlantic Ocean. Geochem. Tech. Rept., 8:803.

Crook, K. A., 1974. Lithogenesis and geotectonics: The significance of compositional variation in flysch arenites (graywackes). Modern and Ancient Geosynclinal Sedimentation: (Tulsa, Okla. Proc. Sym. Madison, Wisc.), 74:304-309.

Drits, V. A., and Kossovskaja, A. G., 1980. Geocrystallochemistry of rock-forming diactohedral smectites. Lithol. Miner. Resour., 1: 84-114.

Goldberg, D., and Arrenius, G. O., 1958. Chemistry of Pacific pelagic sediments. Geochim. Cosmochim. Acta, 13:1134-1159.

Hein, J. R., O'Nell, J. R., and Jones, M. G., 1979. Origin of authigenic carbonates in sediment from the deep-Bering Sea. Sedimentology, 26:681-705.

Kossovskaya, A. G., 1975. Geocrystallochemistry in the solution of geological problems. Crystallochemistry of Minerals and Geological Problems: Moscow (Nauka), pp. 7-18.

Kurnosov, V. B., Mikhailov, M. A., and Shevchenko, A. Ya., in press. Mineralogy and geochemistry of sediments and secondary alteration products of basalts of the Bering Sea and northern Pacific. Geology of the Bering Sea: Vladivostok.

Landergreen, S., 1964. On the geochemistry of deep-sea sediments. Bull. Calif. Div. Mines Geol., 10:57-79.

Markevich, P. V., and Chudaev, O. V., 1979. On the composition of sandstones from flysch formations of the Sikhote Alin and Kam- 
chatka. Geochemistry and Mineralogy of Sedimentary Complexes of the Soviet Far East: Vladivostok, pp. 3-20.

Middleton, G., 1960. Chemical composition of sandstones. Geol. Soc. Am. Bull., Vol. 7.

Mikhailov, M. A., 1980. Petrochemistry and geochemistry of sediments from Komandorskaja basin. Geology of Komandorskaja Basin: Vladivostok, pp. 47-63.

Murdmaa, I. O., Gordeev, V. V., Emelyanov, E. M., et al., 1979. Inorganic geochemistry of Leg 43 sediments. In Tucholke, B. E., Vogt, P. R., et al., Init. Repts. DSDP, 43: Washington (U.S. Govt. Printing Office), 675-694.
Murdmaa, I. O., Gordeev, V. V., Kuzmina T. N., et al., 1980. Geochemistry of the Japan Trench sediments. In Scientific Party, et al. Init. Repts. DSDP, 56-57, Pt. 2: Washington (U.S. Govt. Printing Office), 1213-1232.

Ronov, A. B., Girin, Yu. P., Kazakov, G. A., et al., 1965. Comparative geochemistry of geosynclinal and platform sedimentary units. Geokhim, 8:137-162.

Schutov, V. D., 1975. Mineral Paragenesis of Graywacke Complexes: Moscow (Nauka).

Schwab, F. L., 1971. Geosynclinal composition and the new global tectonics. J. Sed. Petrol., 71(4):191-208. 

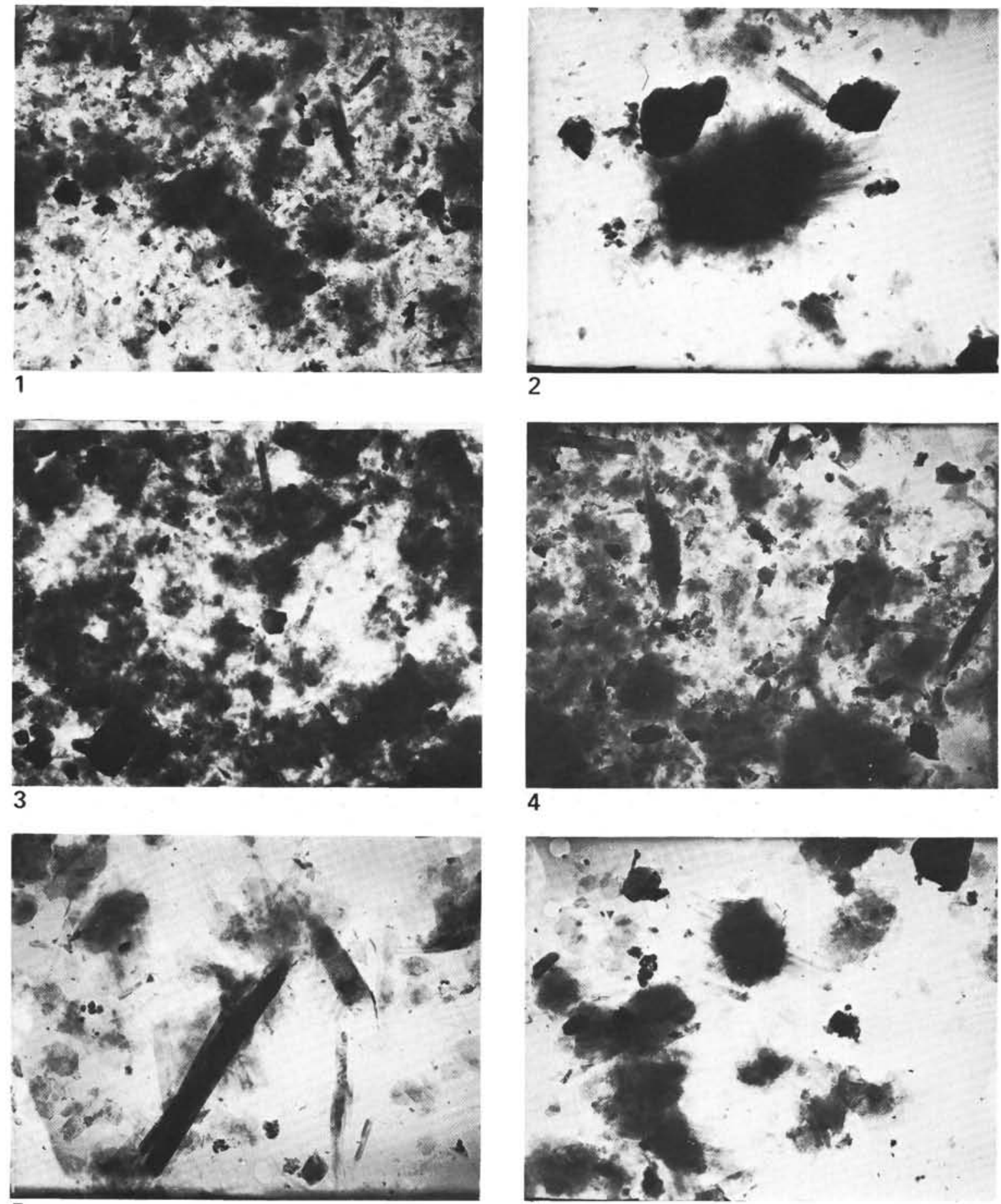

5

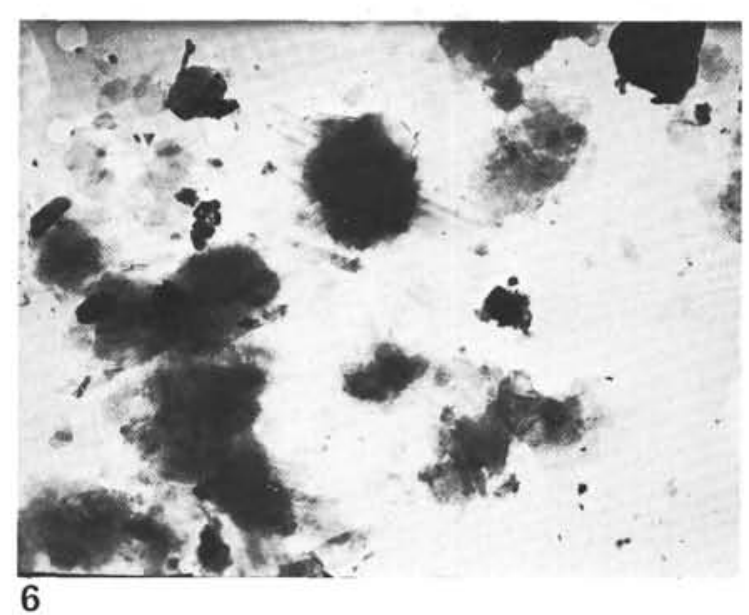

Plate 1. Electron microscope photographs of clay minerals in sediments from the mouth of the Gulf of California. 1, 2. Smectites, Sample 482B-107, 4-6 cm, (1) $\times 12,000$, (2) $\times 18,000$. 3. Mixed-layer hydromica-montmorillonite, Sample 482D-9-1, 3-7 cm, $\times 10,000$. 4, 5, 6. Mixed-layer clay minerals, (4) Sample 485A-28-1, 148-150 cm, $\times 12,000$, (5) Sample 485A-38-1, 98-100 cm, $\times 12,000$, (6) Sample 485A-38-1, 98-100 cm, $\times 12,000$. 


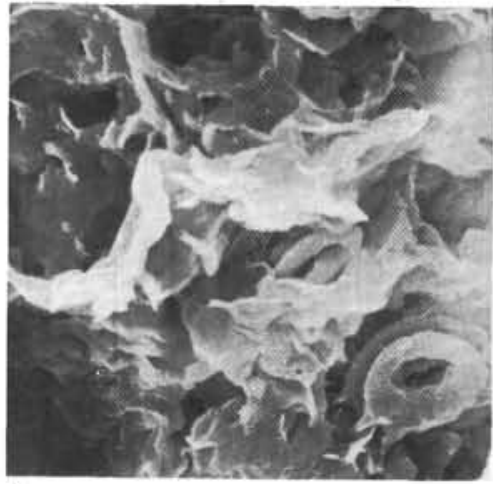

1

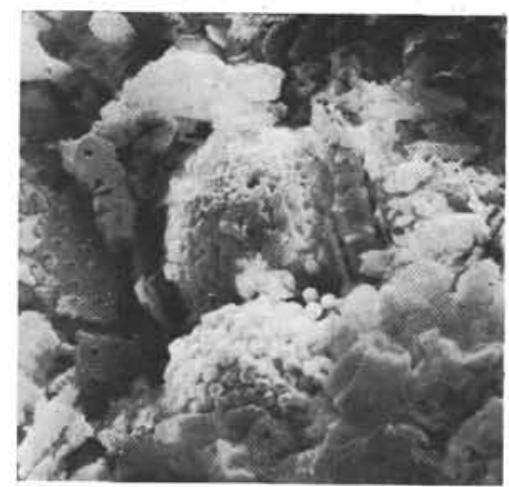

4

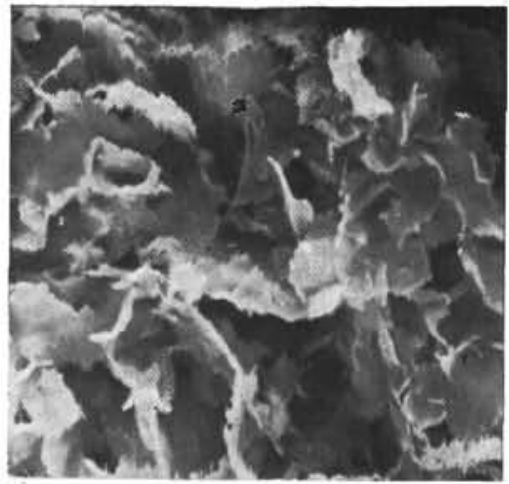

2

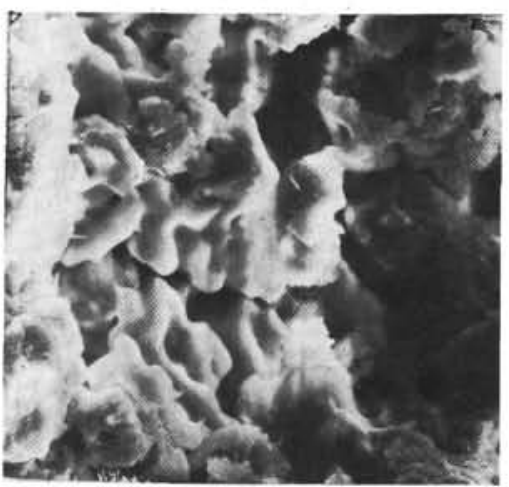

5

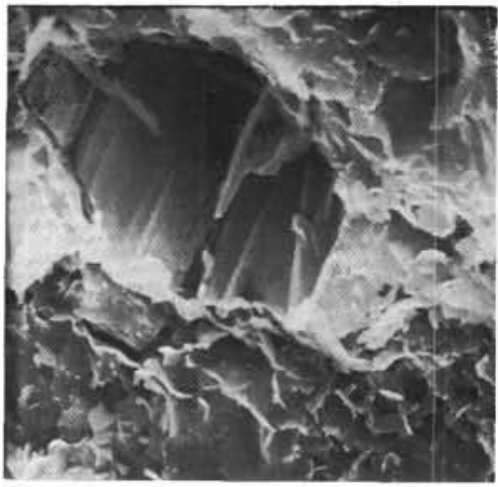

3

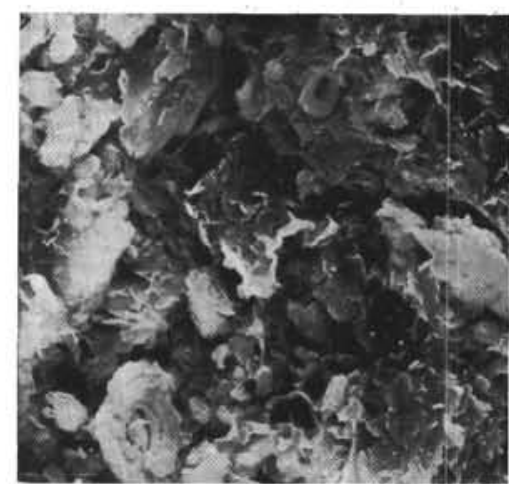

6

Plate 2. Scanning electron microscope photographs of sediments from the mouth of the Gulf of California. 1. Authigenic smectite and coccoliths, $\times 1,500$, Sample 482D-5-2, 60-63 cm. 2. Mixed-layer illite-montmorillonite ( + mica), Sample 482D-9-1, 5-7 cm, $\times 1500.3$. Zeolites, $\times 1,500$, Sample 482D-9-1, 5-7 cm. 4. Diatoms, pyrite, and smectite, $\times 450$, Sample 485-1-2, 90-94 cm. 5. Sintered(?) crust of authigenic clay minerals, $\times 250$, Sample $485 \mathrm{~A}-11-3,35-37 \mathrm{~cm}$. 6 . Mixed-layer clay minerals and coccoliths, $\times 750$, Sample $485 \mathrm{~A}-28-1,148-150 \mathrm{~cm}$. 


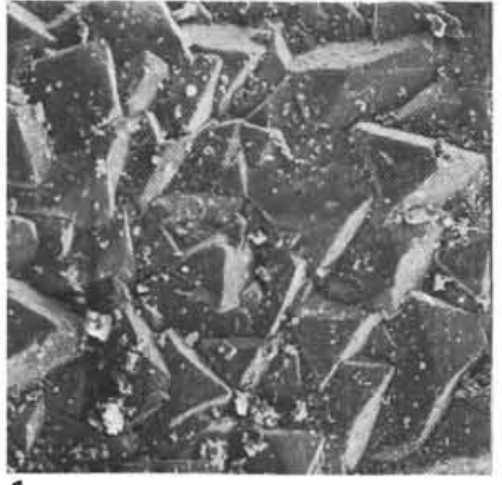

1

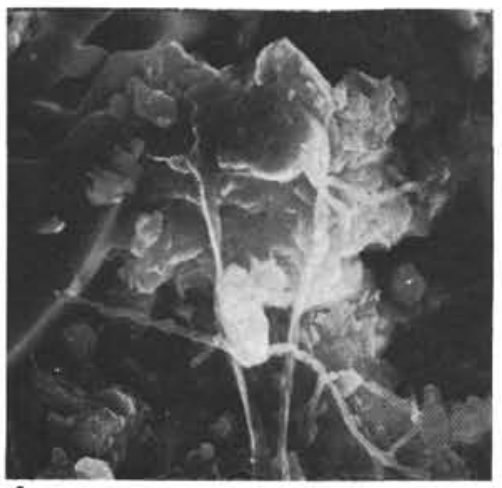

4

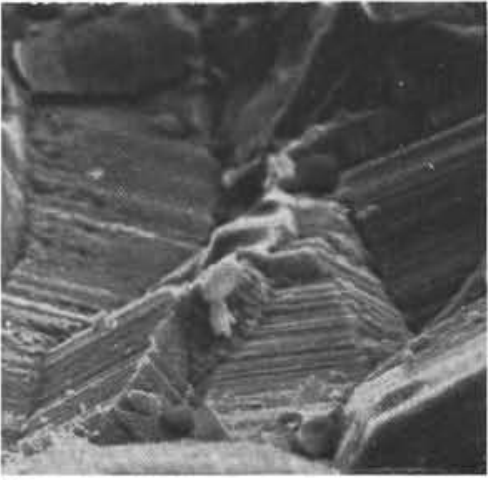

2

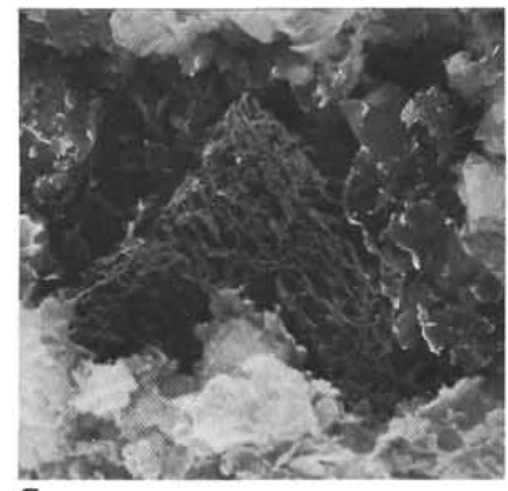

5

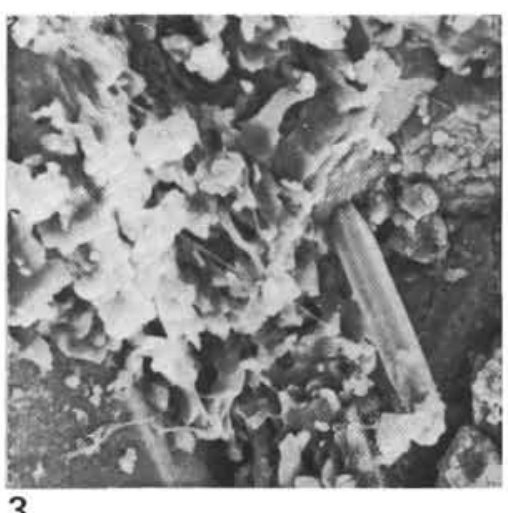

3

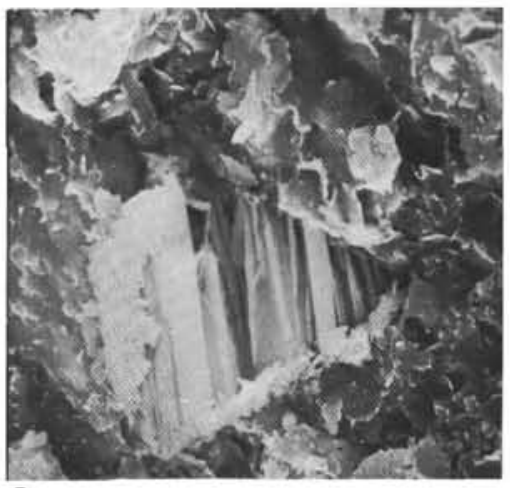

6

Plate 3. Scanning electron microscope photographs of secondary minerals in sediments from the mouth of the Gulf of California, Leg 65 . 1-4. Authigenic vein minerals, Sample 485A-38-1, 94-96 cm, (1) pyrite, $\times 25$, (2) pyrite, $\times 250$, (3) $\times 150,(4) \times 500$. 5, 6. Authigenic minerals in sediments, Sample 485A-38-1, 94-96 cm, (5) $\times 750$, (6) zeolites and clay minerals, $\times 750$. 